\title{
SPORTS SYSTEM IN THE INDEPENDENT STATE OF THE REPUBLIC OF SERBIA - FROM THE PRUDENT BEGINNING TO THE EXHAUSTING STATE INTERVENTIONISM
}

\author{
SISTEMA DEL DEPORTE EN LA REPUBLICA SERBIA COMO \\ ESTADO INDEPENDIENTE - DE UN INICIO PREMEDITADO AL \\ INTERVENCIONISMO ESTATAL AGOTADOR
}

\author{
Branislav Jevtić \\ Faculty of Sport and Physical Education, University of Belgrade, Serbia
}

\begin{abstract}
The subject of this paper were the changes in the National Sports System (NSS) lasting since the Republic of Serbia gained its full state independence (in May 2006) until present. National sports organizations have initiated those changes related to sports and overall culture and science of physical activity as well. The changes have been initiated in the belief that they will be expedient for the development of sports and society in Serbia. The documents include the facts about the aspiration of the then-leaders towards a consolidated model of sports, based on its broad autonomy. The changes have been planned to occur with the logistic and financial assistance of the actors outside the sports system, including the state (central government and local self-government units). In the restricted conditions of the socio-economic development of Serbia and the Serbian political system, the changes have also occurred with the participation of the state, whereby its support (2006-2007), and partnership (2008-2010) were registered, and since 2011, the political, and then legal (legislative) "consolidation" of the national sports in favour of the state - politics has been established. Everything that has been done in the sports system in Serbia since May 2006 can be assessed and evaluated in relation to various criteria, and primarily in relation to the results achieved by athletes, but also in relation to: the organization of major single-sport and multisport competitions; the development of individual areas relevant for the affirmation and humanization of national sports (sports medicine and protection of athletes, anti-doping, Paralympic sports, women's participation in sport...); allocation for sports; citizens' participation in physical activity and mass sports... but also according to the criterion of the sports system management and consolidation and the impacts of the state and politics on sports. In regard to the latter criterion, this paper examined its development and epilogue to the NSS. The conclusion is that the sports system continues to search for its value, organizational, program and managerial identity, and that the changes in the Serbian sports system have "abandoned" the prudent and innovative beginning leading to the exhausting and unpromising state interventionism of an unknown outcome!
\end{abstract}

Key words: NATIONAL SPORTS SYSTEM / MANAGEMENT / STATE INTERVENTIONISM / SPORTS AUTONOMY AND SPECIFICITY / SERBIA

\begin{abstract}
EXTRATO
El objetivo del presente trabajo son los cambios en el sistema nacional del deporte (SND) que perduran desde la plena independencia estatal de la República de Serbia (desde el mes de mayo del año 2016) hasta la fecha. Las organizaciones deportivas nacionales fueron las que iniciaron los cambios referentes tanto al deporte, como también a la cultura y la ciencia de la actividad física. Los cambios empezaron creando que los mismos sean convenientes para el desarrollo del deporte y de la sociedad en Serbia. Los documentos contienen los hechos de la aspiración de los líderes de la época al modelo de deporte consolidado, fundado en su amplia autonomía. Se había planificado que los cambios se desarrollen con la ayuda logística y financiera de los actores fuera del mismo sistema del deporte, incluyendo también el Estado (central y las unidades de autonomía local). En las circunstancias limitadas del desarrollo socialeconómico y el sistema político de Serbia, los cambios se desarrollaron con la participación del Estado, con lo que se nota su apoyo (20062007), su asociación (2008-2010), para, a partir del 2011, establecer la "consolidación" política y luego legal del deporte nacional a favor del Estado - política. Todo lo hecho desde el mes de mayo del año 2006 en el sistema del deporte en Serbia puede valorizarse en relación con los distintos criterios, ante todo, en relación con los resultados de los deportistas, pero también en relación con la organización de grandes competencias individuales y multideportivas; desarrollo de algunos sectores de importancia para la afirmación y armonización del deporte nacional (la protección deportivo-médica de los deportistas, el antidopaje, el deporte paraolímpico, la participación de mujeres en el deporte...), asignaciones para el deporte, participación de los ciudadanos en la actividad física y deporte de masas... pero también a través del criterio de la gestión y consolidación del sistema de deporte y la influencia del Estado y de la política en el deporte. En relación con el último criterio mencionado, en este trabajo se estudió su desarrollo y epílogo en cuanto el SND. La conclusión es que es sistema del deporte sigue buscando sus valores, su identidad organizativa, de programa y de gestión, así como también que los cambios del sistema de deporte en Serbia "desviaron" de su inicio premeditado e innovador hacia el intervencionismo estatal agotador y poco prometedor con un resultado desconocido!
\end{abstract}

Palabras claves: SISTEMA NACIONAL DEL DEPORTE / GESTIÓN/ INTERVENCIONISMO ESTATAL / AUTONOMÍA Y COSAS ESPECIFICAS DEL DEPORTE / SERBI 


\section{INTRODUCTION}

The common denominator of each state in the $21^{\text {st }}$ century is its symbols (flag, anthem...), its cultural distinctiveness, sustainable development, as well as the national system of sports (NSS), which creates systemic assumptions both for the development of the sport itself and for transfer the numerous values of sports towards the progress of the society and every member of it (Blouce, Smith, 2010).

The nations do not create winners; they are neither victorious nor losers. Each nation strives for the system - "Holy Grail", which will promote educational and value in sports, and will create conditions for the success of individuals and teams in international competitions. It has become evident that the criteria for evaluating one NSS must be established in relation to the unity of its factors, the role and responsibilities, the staff, the organizational framework... The tendencies registered with the NSS are also ongoing analyses leading to the selection of more efficient methods and content in the strategy of achieving a national and international mission of sport. And it, the mission of sports in the $21^{\text {st }}$ century is the advancement of society and every individual through participation in sport (from participant to top and elite), which has made sport a part of the cultural value and peculiarity of the society to which it belongs and within which the NSS is formed and built as a system of possibilities for all citizens, regions and areas to participate in sports. In addition, the NSS involves the organizational and functional connection of a large number of actors according to the proclaimed directions of the activities of the sport and the Olympic movement. In other words, the NSS contains and implies the fulfilment of internal factors of sport and its environment, which is why it is established and developed around the cultural, historical and economic characteristics of the society to which it belongs, that is, it must fulfil the external criteria for participation in a structured and recognized sports and Olympic movement (Evtič, 2013).

Each NSS relies on three pillars. The first pillar is the society to which this system belongs. The second pillar builds the structure of the system itself, while the third pillar is filled with actors from the environment of the sport itself and its national system (De Bosscher, Bingham, Shibil, van Bottenberg, De Knopp, 2008).
Since there is a foundation in the value and cultural being of the society to which it belongs (the first pillar), therefore, when changes of the whole or parts of the whole system of the sport (the second pillar) occur, then many questions about the course and outcomes of the changes are posed, such as: "the importance of change, the new organizational and management structure, the realism and the achievability of the proclaimed goals, the engagement of internal sports resources, the way of management, the dynamics and scope of organizational changes, the character and the effects the status of the administration, the status of volunteers, the expectations of the actors and their members, and the like" (Camy, Robinson, 2007).

Changes in the system involve not only the change of organizational and management units of sport, but above all the change in its value orientation and cultural context and are carried out in accordance with the economic power of society (Bergsgard, Holihan, Mangset, Nodland, Rommetvedt, 2007). In other words, changes to the NSS are a complex multiyear process that is planned and implemented using qualitative methods and techniques from process sociology (Edwards, Skinner, 2009) - analysis of the management and management process in sport - description of the phenomenon, detection of connections, as well as the formation of conclusions about the system sport as the subject of future changes (Jevtić, 2011a). In accordance with the aforementioned, but also somewhat broader, outside the context of this paper, changes in the sports system in Serbia (the subject of this work) that have been taking place since 2006, from the first days of its full state independence, should be considered. The goals and directions of these changes can be learned more from several documents adopted at the level of the sports system, predominantly at the National Olympic Committee (NOC), that is, through two sports laws (2009 and 2016) and two sports strategies that were adopted in 2009 and 2013 as government documents of the Republic of Serbia.

In the first month of the state independence of Serbia, a common platform of representatives of the system of sports of these days and the Government of the Republic of Serbia was adopted, which through the document "The conceptual framework of the new system of sports of Serbia", opened the process of change and created the basis for organizational and functional evaluation, and then the evolution of the previous system of sports - "The conceptual 
framework contains links based on the needs of athletes and citizens, the sport tradition, the influence of national and international factors on the development of sports..." is stated, among other things, in the Minutes from this Meeting (Jevtić, 2011b). The adopted framework specifies the directions that the sports system functions according to the model of sports of all citizens, that is, on the basis of the "mature" participatory sport system. In this direction, as the priorities of further development children's and youth sports are sorted out as a lobby for lifelong engagement in physical activity and acquisition of healthy lifestyle, as well as entering the top and elite sport (winning medals at OG, WC, EC) and preserving international competitiveness of results. The framework defined the state's involvement in the regulation of the sports environment, determined the level of centralization, while the sport management envisioned coordination between the Sports Council (to be established), the Olympic Committee of Serbia and the Sports Association of Serbia, as a territorial national sports organization. In other words, it has been envisaged that the management of the sport system in Serbia takes place through a confederal model, as it is in Germany and the countries of Scandinavia. Like any document with this and similar issues, this document also highlights the need to preserve autonomy and respect the specificity of the Serbian sports movement. The framework unambiguously contains a break with the practice of organizing and managing sports from the last decade of the $20^{\text {th }}$ century. However, like any other concept document, neither this Framework had the capacity, nor the mandate to fully regulate the system of sports, so that the issues, and above all those concerning training facilities and competitions, financing sports as well as sport in municipalities and cities (local level), regions, capital city..., place and role of the state..., remained to be developed through the national strategy of sports and to be translated into adequate documents of all actors of sports and its environment! The framework was aimed at "coming" to an efficient model of the sports system, that this path runs through the application of science in both immediate training and sporting organization, and in that direction the Faculty of Sport and Physical Education of the University of Belgrade is recognized as a national institution that is capable of taking over the tasks of scientific development and being the driving force of the members and the whole of the
Serbian sports system towards change through its chairs and other organizational units (departments) (Jevtić, 2010).

Within the two sports development strategies adopted as documents of the Government of the Republic of Serbia, it has been stated that both have emerged as an expression, but also as the need to create those activities that would support the value and organizational aspirations of sports, primarily those related to: (1) increasing participation of citizens of all ages (participatory - mass sports), (2) creating conditions for human growth of children through sports (children's sport), (3) achieving and maintaining top and elite sports results (elite sport), (goverment sports strategies, 2009 and 2013). Unfortunately, the system of sports in Serbia chronically misses the documents of the higher cognitive level, the organizational, value, utilitarian... framework, based on the facts obtained by the scientific approach in the process of knowing and managing changes. Despite the fact that there are dozens of faculties of sports and two sports institutes in Serbia, and therefore, it is a large and respectable academic community, nevertheless, it does not want or is not able to recognize the needs of sports, and therefore of Serbian society as well. In other words, there are no studies that would lead to a more dynamic development of the NSS based on facts tested in best practice and confirmed by methods of scientific knowledge. The third mission of the university in the field of sports is not realized (Jevtić, 2017).

\section{ABOUT THE SYSTEM OF SPORT OF SERBIA}

\section{I}

The Republic of Serbia has been independent as a state since May 2006. However, the changes in the sports system started much earlier, immediately after the political changes of October 2000. Changes in the sports system dominated through the activities of the NOC and through projects such as the completion of the Republic Institute for Sport, the Museum of Sports and Olympics, the nomination for the organization of the European Youth Olympic Festival (EYOF), the organization of national and 
international conferences and seminars. The National Olympic Committee also focused on membership in the Council of Europe sports bodies (EPAS), the European non-governmental sports organization (ENGSO). The participation in the IOC programs through which students from Serbia stayed in Olympia through which some of the sports personnel of Serbia were educated through master studies of management of sport organization (MEMOS) was not "refused". At the time, the NOK also implemented programs of children's sports, affirmation of women in sport, ecology and culture through sport...

Despite the significant number of programs and activities of the NOC, it was not nearly enough to build an efficient and modern NSS, to solve problems, such as staffing and a large number of inherited problems, challenges and confusion (Table 1). Each of the sports organizations, as well as each of the occupations involved in the work of the sports system, identified problems and delays in the area of their activities and competencies.

Table 1 Elements of the national sports system as the basis for the development of sports and sports branches (Digel, 2001).

\begin{tabular}{ll}
\hline - historical circumstances and Olympic tradition & - system of competition \\
- ideological design & - sports facilities \\
- interest in elite sports & - a system of awarding athletes \\
- the organizational structure of the system & - the rewarding system of coaches \\
- staff structure (employees and volunteers) & - social safety for athletes \\
- finance & - social security for coaches \\
- Athletes & - sports and medical control and protection \\
- coaches & - fight against doping \\
- talent identification & - development priorities \\
- promotion of talent & - trends in the development of sports \\
- training technology & - specific national interests \\
\hline
\end{tabular}

Detected problems within the sports system in Serbia, and in 2006 were not small. They were assessed as

limiting to the overall development of sports, both at the top level and at the level of participatory sport, that is, they were detected both at the level of the national sports organization (NSO) and at the level of the sports club (Jevtić, 2006, 2006a). Therefore, despite the best desire to solve all the problems of sport, as soon as possible, through a rational approach through causal, functional analysis and the analysis of needs, priorities and named activities have to be determined which should lead to the progress of the system. Among them, in the first place, the choice of "value compass" for the future NSS, the definition of priorities, the choice of activities that were estimated to lead to evolutionary changes without slowing down the sport itself (training and competition) were found (Jevtić, 2010). At the beginning of the change little was known about the intentions in the development of the Serbian society, it was therefore difficult to plan the development of the national sport without knowing about the general and special development agendas of numerous social actors and systems. For sports, but also for other areas of society, there was, and perhaps it remained, a common, chronic lack of systematic and systematic monitoring of change and directing actors of social reality towards higher goals and effective levels of organization and democracy. Therefore, it should be emphasized that, despite dozens of academic institutions in the field of physical education and sports, NSS studies are rare. For the most part or not, with this, the many visible and solvable problems of the sport have, over time, become "unsolvable" and translated into its "suppressed reality", making a significant part of the NSS changes postponed indefinitely! 


\section{II}

Numerous activities that accompany the change of the Serbian sports system have their roots in the "visionary of sports lovers and erudite for the prosperity of the citizens of the Kingdom of Serbia" (Vukašinović, 2018) and the decades-long development of sport and physical culture through the Yugoslav society. Of the new ones, from the period since June 2006, the significance and timeliness of the "Conceptual Framework for the New System of Sports of Serbia" should be emphasized, which was expected to stimulate and direct the changes of the NSS. This document came after a multilateral analysis of the functioning and analysis of the needs of the Serbian sports system in the new sports, social, political and international environment. Although some might have expected that sport would show some form of resistance to change, it began with the same ones already in the first days of state independence, and they were dominating around the NOC. Unfortunately, the shallowness of the system, the coming sporting events and the priority orientation towards preserving the competitiveness of the results of Serbian athletes (teams and individuals) has determined that the changes begin with the issue of top sport and its two assumptions: (a) athletes (exercised according to athletes and his personal, social and training-needs needs have been made to the sport-centric setting of the system as one of the values of the sport of the $21^{\text {st }}$ century), (b) organizational, managerial care and professionalization of the relationship between the factors of the sports system, from the sports club to the National Olympic Committee itself. What is lacking in these first activities and steps towards the new system of sports is that which is lacking in today's agenda of its development, as well as the fundamental issues of the development of Serbian society through sport, such as: organization and sport management (governance and independence of the NSS , quality management of sports organizations...), place and role of professions and occupations in sport (affirmation of profession sports coach and new professions in sports...), career of top athletes (social security and career after sports), to the question of technology of training (the promptness and efficiency of the training and competition process, identification, detection and development of sports talent, training centres...). In addition to these, the ways of destigmatizing and re-socializing certain groups of society through sport are still being sought.
The reason for this, as well as other program and system reductions, should be sought, as in the kind of "legacy" of ignorance and non-recognition of the mission of sport, but also in: (a) the beginner of the change and the mission of its operation (this was in this case NOC, today the Olympic Committee of Serbia - NOCSrb); (b) the cause of change (priority to preserve the competitiveness of the top sporting result and the preparations of athletes and delegations for participation in the Beijing Olympic Games, 2008), (c) historical, economic, political... context of social changes brought about by state independence; (d) the habits and expectations that filled out relationships and determined the directions of sport development during the period of socialism; (e) insufficient knowledge of the NSS, its structure and direction of change; (f) the lack of an interpretative framework for a new understanding of the mission of sport in accordance with the needs of the $21^{\text {st }}$ century... (g) the "shallowness" of the system followed and determined by limited value, organizational, human and technological resources, personnel to deliver society and sport a strategic paradigm that will lead to a new national reality.

Summarizing it, it can be said that the NOC, as the initiator of change, responsibly approached the challenges of changing the state status of the Republic of Serbia in the sports field. The chosen path of operation corresponded to the principles of "deep understanding of the problem". In other words, what was done from this period, although it was established around the program for participation in the Olympic Games (Olympic Programme - OP), was, however, filled with a comprehensive overview of the overall pro-Olympian sport, both in its technological and resultant sense and meaning, organizational and scientific as well as in the socio-cultural context of sport's activity on the changes in Serbian society (Chart 1). Although it was possible to approach it from the relativistic side (the norms and criteria for participation in competitions as the only criterion) in resolving the problems and challenges of sport, nevertheless, respecting the context of the modern national sports organization (NSO), the need of sports and the athletes themselves, the NOC has opted for the strategy of natural progress (progress in a number of areas that are building a comprehensive system of national and pro-Olympian sports as an axiom of national sports), making it a profound approach to the national sport, that is, sports perceived as: "the broader context profoundly linked 
to the socio-cultural and moral values of the freedom and responsibility of all actors of the sports system, above all athletes, coaches, sports leaders "(Loland, 2009). Therefore, it should not be surprising that even today's motto of the OKS "Road of Real Values" is the expression of a wider vision of the mission and aspiration of this leading NSO to pursue the value of the development of sports and society of Serbia (www.oks.org.rs).

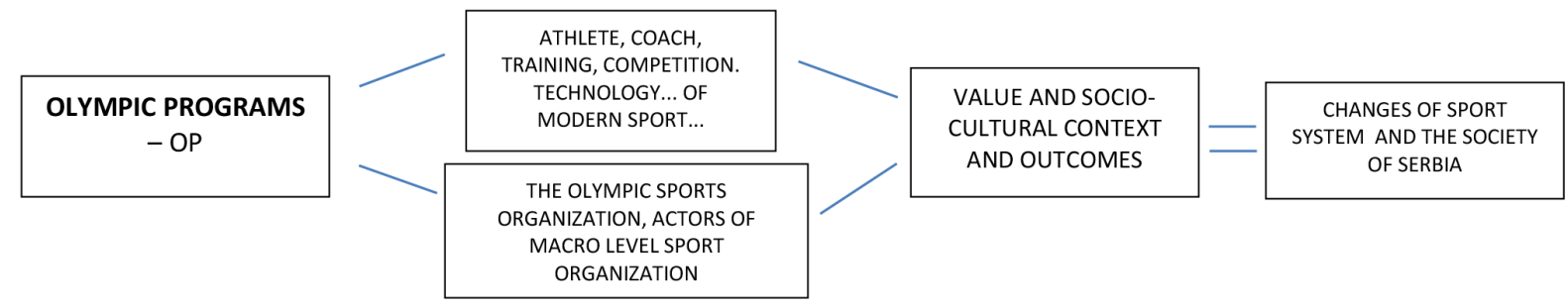

Chart 1 The Olympic programs in the context of changes of the system of sports and the society of Serbia

Although the immediate goal is to prepare for participation in the Olympic Games, the context of the OP is broader and includes: encouraging the spiritual and physical harmony of the individual, his aspiration towards perfection and achievement, fostering the relation of equality, friendship, tolerance, understanding, protection of the identity of the athlete, teams, delegations, sports and Olympics themselves, the construction of competition preferences and high degree of competitiveness, the improvement of the environment and its effectiveness in meeting the athletes' preferences, the athlete's social safety and zero tolerance (Jevtić, 2011b, c).

\section{III}

Process, structural and organizational analyses made in the Serbian sports system indicate that they are guided similarly, but also at the same time, in particular, compared to comparative European systems of sport (Evtič, 2013). A more detailed analysis of the changes in most European sports systems, those that began with the changes in the 1980s, indicates that: changes last for more than a decade; changes are managed from one (consolidated model) or more centres (non-consolidated model); care of the athlete is in the centre of change; changes are related to the political support that is most often developed around elite sports; changes are taking place through the coordination of resources, technologies, processes, staff, as a decision process and activities based on the fulfilment of specific tasks (DeSienci 1990). A decade later, it can be concluded that the system of sports in the state-independent Republic of Serbia, among other things, changed according to DeSienci, but also that the intensity of these changes was variable and unpredictable, both by the outcome of the NSS and the actors of those changes. In other words, it is possible to determine some peculiarities in the changes in the Serbian sports system, which can be said to be not good for its future status, and which relate primarily to:

- maintaining habits from socialism or still maintaining socialism? which is reflected in the expectation of the sport itself from the giving of the state;

- the absence of autonomous sports bodies that govern the sport system and which are responsible for planning development, monitoring and evaluation of the sport;

- legal regulation of sports (sports laws of 2009 and 2016), which is in a large number of members contrary to the mission of sports and its Pan-European trends and values;

- the absence of legacies of the Serbian sport and society after the organization of international sports competitions;

- Recognizing and disregarding European conventions and legislation related to sports, according to which a large number of problems are registered in respecting the specificity of sports and thus directly endangering the maintenance of its autonomy ${ }^{1)}$;

\footnotetext{
1) The principle of the autonomy of the Olympic and Sports Movement is defined by the members of the IOC Charter, the Statutes of the National Olympic Committees. Autonomy (the right to freely determine the rules by which individuals and organizations will be governed and managed without interfering with external factors) is also defended by the statutes of international and national sports organizations. All documents relating to the autonomy of sports constitute the sports legislation of the sportswear (Lex sportive) of the Olympic and Sports Movement. The rights of sports and athletes are protected at the Court of Arbitration for Sport, as well as by the rules of the World Anti-Doping Agency (WADA), which, through the UN and the Council of Europe, acts
} 
- Adoption of strategic documents for the development of sports on the governmental, but not at the level of the sports system itself (government strategy for sport development 2009 and 2013);

- a chronic presence, as well as the influence of politics that has, over time, received a mixture of interference with internal issues of the sport itself and sports industries;

- absence of action plans for the development of participatory - mass sports, in particular through linking with sport in institutions (school sport, university sport, police, army) and commercial sports;

- the absence of a clear definition of professional sport and the creation of preconditions for its affirmation through sustainable sportsfinancial flows;

- neglected international sports cooperation.

The impression that the sport, in the first step of searching for the integrity of its system and autonomous identity, did not recognize its being, disregarded the function that was destined to it in this age, and did not recognize the structure on which national sport is established and built (Figure 1), which is why sports in institutions and private sports are left out of the context of change, and therefore out of the whole of the system of sports, which, for this reason, can be called "shallow", unprofitable, outdated, non-inventive, .

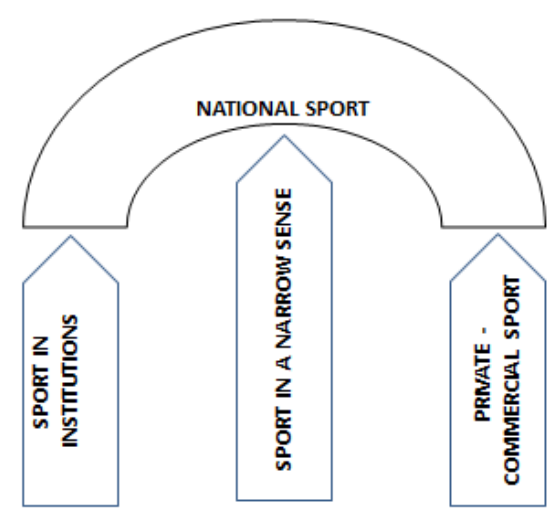

Picture 1 Pillars of national sport

towards members in the „doping of clean sports” (Šuput, 2015 ). Sports relations, in relation to business and commercial laws, are regulated by Lex Mercatoria normative (Carrard, 2006).
IV

As stated in the previous allegations, the sport itself initiated changes in the first months of Serbia's independence, among which the central one was the one from which the system was to be consolidated, which included value and organizational design in sport management from the sport itself (setting for a consolidated model of sport management). It was possible to establish a belief on consolidation with the pre-defined three organizational units - levels of the new Serbian sports system (micro-, meso- and macro- level, Chart 2). In view of today's perspective, it can be said that, at the very beginning of their changes, the changes were in line with the experience of a number of European sports systems referred to by research and analytical studies (Bergsgard et al, 2007, De Bosscher et al, 2008). Thus, in Serbia, at the first or micro level, a solution to the sport of inherent problems, such as the care of the athletes and the continuous development of a quality and efficient training process, has been pursued. From this level it was expected to bring answers to the questions of interest as a sports coach, as well as other affirmations and new professions that are important for the efficient and quality performance of sports activities. The $2006 \mathrm{draft}$ concept foresees a national coaching organization that has not been established to this day, so that all the professional and questions of this profession have remained neglected, while the preparations for the affirmation of the profession have not started sport, it is better to say nobody knows who should do it!

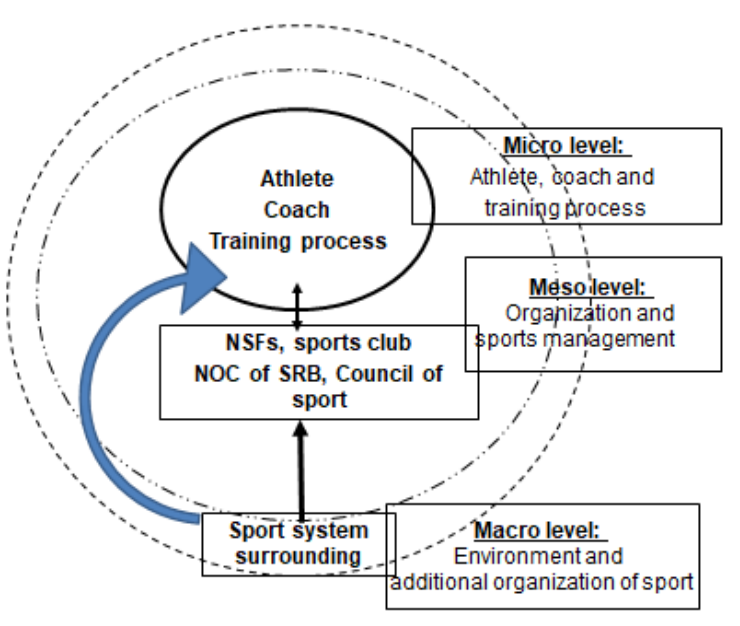

Chart 2 Levels and actors of National Sports System 


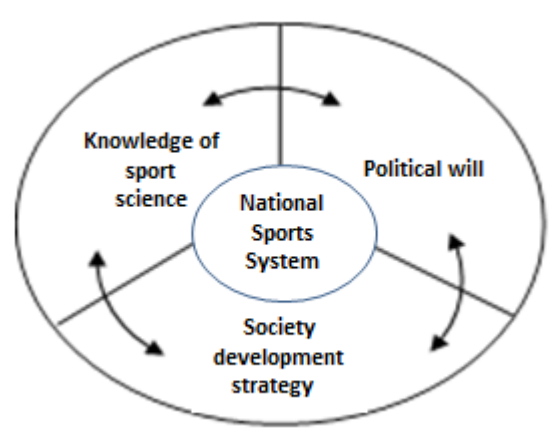

Chart 3 Factors that define National Sports System

At the second or meso- level, organization and management of the sport system takes place. One of the goals of the players of this level is the endeavour to connect sport with complementary strategies for the development of Serbian society (Chart 3). It was believed that the ministry in charge of sport (Ministry of Youth and Sports, MOS) would work on the integration of society through sport. This, today it can be said that a lay belief took into account neither the factor of political order, political will and political culture, nor the passivity of science (Chart 3). In addition, it was believed that in Serbia, as well as at the United Nations level, sport would be recognized as an integrative process in the realization of the goals of the $21^{\text {st }}$ century (Sport to the Millennium Goals), that the changes to the NSS would take place as well at the beginning of the 20th century when the NOC was founded (the Olympic Club of Serbia, 1912) and with the idea of the leadership taken over by the IOC arising from classical liberalism and Lock's theory of social agreement ${ }^{2}$. Serbia was then at the same position as the IOC (founded in 1896) and the World Football Association (FIFA, founded in 1904), and they appreciated that the essence of autonomous sports would be lost when the "ghost figure of a dangerous and imprecise country" appeared (Chappelet, 2010).

One of the ways and means that most effectively connects all three levels and all factors of the national system of sports are sports sciences, which, unfortunately to Serbia, were accepted neither by its structure, nor essentially until the present. New study programs at the Faculty of Sport and Physical Education of the University of Belgrade in 2005 did not last long enough to evaluate their effect on the sports system and the affirmation of sports sciences as an umbrella scientific field (lasted from 2005-2008). This, the scientific aspiration of the sport itself led by the NOC, can be attributed to the improvement and affirmation of the role of the Republican and Provincial Institutes of Sport Today it can be concluded that at the mezzo- level, a large number of problems have remained unresolved, primarily those related to the non-functioning of the sports organization, both in sports and in the business context. Most sports organizations, even today, do not have the capacity to create a vision of their development, to carry out tasks and operations that, even in part, would be independent of the financial assistance of the third or macro level, to which the political coalition members belong (Table 2).

Table 2 Political ideology and sport (supplemented by Radojević, Jevtić, 2011)

\begin{tabular}{|c|c|c|}
\hline Political direction & A feature of action towards sport & Implications on sport \\
\hline Liberalism & $\begin{array}{l}\text { Minimal interference of the state, } \\
\text { individualization and market orientation }\end{array}$ & $\begin{array}{l}\text { The largest number of resources is directed to } \\
\text { top, elite and commercial sports }\end{array}$ \\
\hline Socialism & $\begin{array}{l}\text { Sport is a means of solving various social } \\
\text { problems and achieving general interests }\end{array}$ & $\begin{array}{l}\text { Direct mixing in all forms of sport, the law } \\
\text { limits activity and development }\end{array}$ \\
\hline Conservatism & $\begin{array}{l}\text { Searching for the goal, the use of public funds } \\
\text { is in the second plan, sports is a business }\end{array}$ & $\begin{array}{l}\text { On the distance from the sport as a private } \\
\text { initiative led by the voluntary sector }\end{array}$ \\
\hline Social Democracy & Equal opportunities for sports & $\begin{array}{l}\text { Direct involvement in sport through the } \\
\text { construction of facilities and the expansion of } \\
\text { the participation of all citizens. Public-private } \\
\text { partnership, sport community }\end{array}$ \\
\hline
\end{tabular}

\footnotetext{
2) In a letter of tolerance, Lok felt that volunteer organizations had the right to independently set their own rules and regulate their relationships. In contrast to this view, Serbia seems to have overtaken the Rousseau's theory of social agreement that leaves little room for independent volunteer organizations.
} 
Although it would be expected that the connection between the meso- and the macro- level is two-way, nevertheless, on the example of Serbia, this is not the case (Chart 2). The state operates unidirectional to the meso level, but also with the wilful measures "skips" this level and directly acts towards the micro level, primarily towards athletes who are in the area of its interest. Therefore, as if it were a virtual, unrealistic connection, while the very relations of the actors of all levels were fulfilled as a superposition of the state over sports, athletes, coaches, and cognitive and value dissonance (cognitive and value disadvantage) for most issues of relevance to the current and the future development of sports and sports branches. Under the pretext of "introducing order", there was a oneway action for actors at all levels of the system, which led to a standstill in the management, and therefore in the democratization of the entire sport and its factors. There is little or no sports organizations that are able to independently turn to their development, through the culture of their organization, preserve the autonomy of their managerial and program decisions and activities. Expectations from state giving displaced and disguised the management of sports and sports industries, which put the sports, cultural and business development of the sports organization indefinitely postponed. This state of affairs is described in more detail in Figure 2, which provides an overview of the business culture analysis for a number of NSOs during their participation in the Olympic Games programs in London (2012). The dominant orientation of the NSO toward the "south of the value compass" is noticeable. A timely analysis would probably point to an even greater orientation of the NSO toward the south of the value compass of organization and operation. In other words, sports branches in Serbia do not meet the management of quality management through their NSOs, which leads to total (overall) quality management, which would also lead to loyal, believing, compromising, methodical, precise, caring, factual in the system of sports in Serbia, solvent sports organizations, human resources to perfect their "final product" (athletes, its result, the sports organization itself, organization of sports competitions, coaches...), but also, more importantly, to improve in business and to organize Serbian society and "ordered" sport in accordance with the definition of sport given by the Council of Europe $^{3)}$, and with the expectations and needs of the citizens of Serbia (Jevtić, 2014).

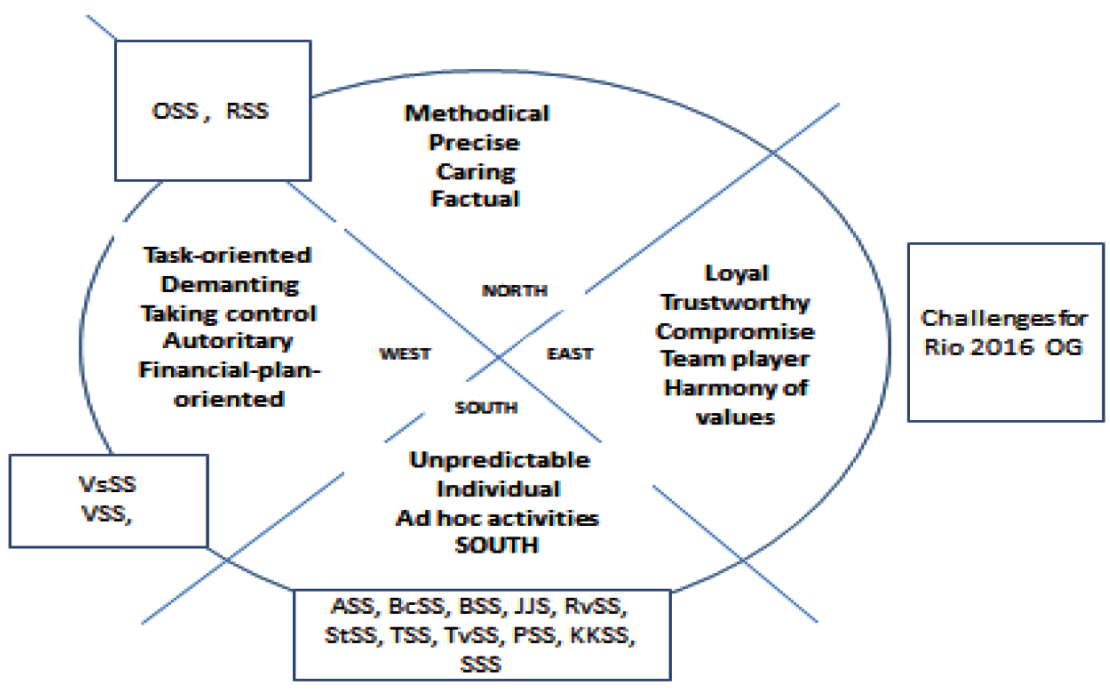

${ }^{\star}$ Abbreviations for NSO of sports: Field and track-ASS, Cycling - BsSS, Boxing - BSS, Judo-JCC, Wrestling-RvSS, Shooting - StSS,
Tennis - TSS, Taekwondo - TvSS, Kayak-canoe-KKSS, Table tennis-StSS, Swimming - PSS, Water polo-VsSS, Rowing-VSS,
Volleyball - OSS, Handball - RSS.

Picture2 Compass model of orientation of certain NSO of Serbia in relation to their assertiveness towards OP (Jevtić, 2013).

\footnotetext{
3) "Sport is an organized activity that achieves cultural values, democratizes society, raises the quality of life and encourages the building of
} 


\section{V}

There are few written sources and documents about the life and reality of the Serbian sports system before the full state independence. Nevertheless, much of the period preceding the state independence can be concluded by analysing the facts and analysing the meaning of the three documents of the NQF, such as the "Athens 2004" and "Beijing 2008" projects, as well as the document "The Conceptual Framework of the New Serbian Sports System". The "Athens 2004" project contains an analysis of qualification results and management of participation in these games. The document "Beijing 2008" shapes the implementation of the OP in the context of the Chart 1. In both cases, these documents are the organizational and technological development of the sports system at the level of international and top sports. On the other hand, the "Conceptual Framework for the New Serbian Sports System" is a document designed to: (1) regulate the overall framework of the Serbian sports system, (2) take over the responsibilities of old and new actors of all three levels of system organization, and (3) distribution of duties in the new national sports system (Jevtić, 2011a).

Common to these documents is that they contain analyses of the sports system, name problems, recognize actors, prescribe activities that should encourage the evolution of the pro-Olympic sport and the whole NSS. The problems that have been detected and the processes identified through these three documents, and with more or less intensity and success since 2006, can be described through two main phases and a greater number of periods. With the separation of phases and periods, it is more precise to describe the efforts and the flow of the process of NSS construction. This also reveals steps (forward) that have determined the degree of acceptance of organizational, financial, managerial contemporaneity, as well as acts and omissions, which have led to a greater number of problems in the realization of the $21^{\text {st }}$ century sports mission. Specifically, in stages:

During the First Phase (2006-2009), deliberate changes that could be characterized as evolutional in terms of their promptness and progressive in terms of building a comprehensive, consistent, modern and stable NSS were taking place. Periods describing the orientation to solving practical problems and

a national identity through the successes of individuals and teams in competitions in demanding international competition". challenges, as well as the selection of activities that led to changes in some of the targeted areas of functioning of the sports system, are primarily registered in the area of sports and medical protection of athletes, antidoping. Belgrade hosted, and OKS was the organizer of the first multisport event in Serbia. The European Youth Olympic Festival (EYOF), held in summer 2007, has resulted in a success but also a number of organizational, material and systematic legacies, as well as a legacy in personnel of various occupations and volunteer organization through sport and a wider social need. This is the stage during which the programs that lead to participation in the Olympic Games (Olympic Programs - OP) are fully developed. There are signs of business and program "healing" of sports organizations. The system is dominated by the intentions of NOK - OKS, while in the part of the organization of the World Student Games Universidad 2009 - significant participation of the state and politics is registered. The National Olympic Committee intensifies the agreement with the state structures, from the central state, the province of Vojvodina, the capital and local community units on the financing of the OP. Answers to a number of problems, which chronically burden athletes, coaches, training process of clubs, were found through joint activity with all levels of state administration. The adoption of the Constitution of Serbia (2006) and the recognition of sports and physical activity in the most important state legal act were seen as a good and opportune solution for many sports issues. And that was not the end! being conscious of restrictions on sport arising from the dual organization of the Ministry of Education and Sport of these days, the sport has compiled and offered a policy to the document requesting the establishment of a ministry in charge of sports. Some of the issues of top-level athletes were solved through the activities of the Association of Olympic Games of Serbia, which was initiated by the Ministry of Education and Sports, and the Government of the Republic of Serbia adopted a decree on national recognitions for athletes and coaches.

During the first phase, the Law on Sports and the First National Strategy for the Development of Sport are intensively implemented. The development of the Strategy was a coordinated effort by members of the sports system and the newly formed MOS. Despite the joint work, this document was adopted only by the Government of the Republic of Serbia. 
There was no adoption at the level of the sports system and the preparation of program documents of sports factors and its environment in accordance with the objectives and action plan of this document. The strategy prioritizes the role of the state in the development of sport, and it can be characterized by cognitive and value dissonance in relation to the needs of the $21^{\text {st }}$ century European sport system. "The MOS Action Plan has chosen the state governance and state initiative, it refers to the system of sports in the narrow sense in an autistic way, it is not oriented towards the development of the players of the system itself, but through state centralism it wants to manage a system of sports that is not part of it. The epilogue of this document is that a large number of planned activities have not been realized "(Jevtić, 2010).

The second phase in the development of the sports system in Serbia lasts since 2009. During this phase, periods dominated by changes that are in accordance with the title of this paper are evident, and they can be seen through the expansion of cognitive and value dissonance, which leads to a departure from the postulate of coordinated action of sports and the state.
The particularity of this phase is the abandonment of the consolidation of the management of the sports system through the National Sports Council. By adopting the Government's strategy for the development of sports, the existing, certain form of partnership relations between sports and the state, turns into the state's efforts to take the leading position and dominance in the realization of selected sports issues. As far as the first, and then the second government strategy for the development of sports came, the data from Table 3 is illustrated more graphically and more than every other comment. The analysis of this table clearly indicates that the Government has recognized and has become the centre of strategic activities of sports in Serbia! The starting point for this and this attitude can be found in the distorted idea of the sport system in the view of MOS (Chart 5). Today, at the expiration of this strategy, the impact on its realization, as well as the implementation of the Action Plan, is a big unknown. In other words, there is not much that will remain as a legacy and experience based practice and value in making a new one, and hope for modern and sport centric strategies.

Table 3 Strategic priorities and distribution of activities for the implementation of the Action Plan of the RS Sport Development Strategy (2013-2018)

\begin{tabular}{|c|c|c|c|c|c|c|c|c|c|c|c|}
\hline \multirow[t]{2}{*}{$\begin{array}{l}\text { Priority areas for } \\
\text { improvement }\end{array}$} & \multirow[t]{2}{*}{$\begin{array}{l}\text { Planned } \\
\text { number of } \\
\text { activities }\end{array}$} & \multicolumn{2}{|c|}{$\begin{array}{l}\text { Central state and } \\
\text { local community } \\
\text { units - JLZ }\end{array}$} & \multicolumn{2}{|c|}{$\begin{array}{c}\text { Sports } \\
\text { institutions and } \\
\text { ADAS }\end{array}$} & \multicolumn{2}{|c|}{$\begin{array}{l}\text { System of sport } \\
\text { (NOC, SAS, } \\
\text { POK, NSO) }\end{array}$} & \multicolumn{2}{|c|}{$\begin{array}{c}\text { Academic } \\
\text { community } \\
\text { and } \\
\text { professional } \\
\text { organizations }\end{array}$} & \multicolumn{2}{|c|}{$\begin{array}{c}\text { Other } \\
\text { participants }\end{array}$} \\
\hline & & $\begin{array}{l}\text { Number of } \\
\text { activities }\end{array}$ & $\%$ & $\begin{array}{l}\text { Number of } \\
\text { activities }\end{array}$ & $\%$ & $\begin{array}{c}\begin{array}{c}\text { Number } \\
\text { of } \\
\text { activities }\end{array} \\
\end{array}$ & $\%$ & $\begin{array}{c}\text { Number } \\
\text { of } \\
\text { activities }\end{array}$ & $\%$ & $\begin{array}{c}\text { Number } \\
\text { of } \\
\text { activities }\end{array}$ & $\%$ \\
\hline Children's sport & 105 & 57 & 54 & & & 42 & 40 & 6 & 6 & & \\
\hline Recreational sport & 138 & 85 & 61,5 & & & 26 & 19 & 4 & 3 & 23 & 17 \\
\hline Elite sport & 68 & 25 & 33,1 & 5 & 7 & 31 & 46 & 7 & 10 & & \\
\hline Sports infrastructure & 39 & 21 & 54 & 7 & 18 & 11 & 28 & & & & \\
\hline $\begin{array}{c}\text { Sport at all levels of } \\
\text { government }\end{array}$ & 138 & 28 & 21 & 54 & 41 & 56 & 42 & & & & \\
\hline Research work in sport & 85 & 20 & 24 & 26 & 31 & 20 & 24 & 19 & 22 & & \\
\hline $\begin{array}{c}\text { Number and } \\
\text { distribution of all } \\
\text { activities (\%) }\end{array}$ & 573 & 236 & 41 & 92 & 16 & 186 & 32 & 36 & 6 & 23 & 4 \\
\hline
\end{tabular}

* The planned participation of sports organizations (shaded) in the implementation of the strategy of sport development 2013-2018 is $32 \%$. The participation of the state and institutions based on state decree, financed from the state budget and not belonging to the sports system is $68 \%$. 
Sport, both from the first, and from the second strategy and accompanying action plans, awaited the affirmation of the sport's specificity and the strengthening of its autonomy. The professionalization of the sports organization itself, as envisaged in the 2009 Strategy, was expected to be completed, and it was envisaged that the standardization of organization (standardization of the structure and standardization of national branch associations, their organization, administration, programs etc.) will be undertaken in the first step (period). As a second step (20102012), the specialization of the sports organization was named (through the principles of attractiveness of sports - physical exercise, talent affirmation, development of resources for top sports). The third step (2012-2013) was to create a "new system of sport in accordance with the needs and expectations of Serbian society in the twenty-first century, but also in accordance with the European Sports Charter, the principles of sport policy for all, the Code of Sports Ethics, the Convention on the Prevention of Violence in Sports, the Convention on the Prevention of Doping in Sport" (Strategy, 2009). The Action Plan for the implementation of 2009-2013 Strategy also provides for the strengthening of the autonomy of sports associations in regulating the internal relations of each sports branch, as well as in determining the directions of development. Autonomy is not a small challenge, because it means that the sport regulates itself, thus achieving its quality, credibility and legitimacy (Chappelet, Bayle, 2005; Chappelet, 2010). In this regard, the sports strategies of the Government of Serbia, both from 2009 and 2013, as well as the Law on Sports (2009), have foreseen the establishment of a National Sports Council. The Sports Council was supposed to play a leading role in the consolidated sports system and it would be the "umbrella" of autonomy and the protection of the specifics of sports and its players in Serbia. Although it was known that the autonomy of sports, as in all its essential forms (political, legal, financial, pyramidal, supervised, functional, negotiating, as well as the autonomy of good governance in sports, (Mrkonjić, 2013)), and in its full capacity, the challenge for older Europe's democracies, however, it was not expected that the realization of this strategic goal would be neglected - suppressed. It was even less expected that changes in the Serbian sports system would not take place according to the instructions of the Council of Europe to protect the sport's autonomy.
Namely, the Council of Europe itself, aware of the vulnerability of sport autonomy from political and state structures, has identified and described the horizontal and vertical network and presented the relations of the actors of these two networks with the aim of protecting the autonomy of sports. Thus, the horizontal network at the level of Europe belongs to the activities of the organization and bodies that are engaged in sports on behalf of the Council of Europe and the European Commission (EPAS), the conference of ministers responsible for sports (MINEPES), professional associations (coaches, teachers of physical education, scientists in sports sciences, managers, faculties of sports and physical education, national training centres...). Vertical network is realized from club level, through NSO, NOC to international sports organizations and the International Olympic Committee itself. Vertical network is the exclusive right to organize the right elements of the sports system (sport in the narrow sense, Picture 1). The CE document prescribes that superposition of the actors from horizontal network over the elements of the vertical network is either prohibited or not justified, as this leads to state interventionism (Chaker, 1999, 2004). In the case of Serbia, a large number of decisions under the jurisdiction of a vertical network are made by the state, as a substitute for unknown policies and interest groups. The above points to the conclusion that the Serbian sports system is not on the path of building a consolidated system and management model, which would make the sport autonomous and autonomous in making decisions of its development, be a partner to all the actors of the society and act in accordance with their agenda and goals of Serbia's development. State interventionism is in force, which is why Serbia is not in the organizational and legislative agreement with the majority of the countries of the European Union, and so in the field of sports, we see a systematically different system and national sport from Slovenia and Croatia with which we made the system of sports of the former SFRY.

The Law on Sport, adopted in 2009, and in particular the Law on Sport of 2016, made it clear that there will be no regulation of the sports system in Serbia in accordance with the needs of $21^{\text {st }}$ century sports. From the initial enthusiasm of 2006, we have reached the state interventionism best described by Chart 5. Although this chart was made up of MOS officials, and it was withdrawn from the public debate 
of the 2013 Strategy, its meaning remained in the textual expression this government document. In other words, the Serbian sports system has denied the right (or did the system deny that right?) To build its independent, autonomous and sporty responsible management side. He did not consolidate in favour of the sport and the Olympic movement. Everything suggests that sports management by the sport itself is not acceptable to the state and political elite of Serbia, which is why they bring directives, laws, regulations, rules, supervise and punish sports organizations. The work is a cognitive-organizational-valuedtechnological-political... dissonance between the beings of the sport, the needs of citizens and the whole of society from one state and political parties on the other.

\section{FROM INNOVATIVE STEPS FORWARD TO STATE INTERVENTIONISM}

Table 4 Conclusions on systemic action on issues of women's participation in sport (Jevtić, 2011v)

\begin{tabular}{|c|c|}
\hline 2010 & 2011 \\
\hline $\begin{array}{l}\text { Analyse the international sports scene and the } \\
\text { way to achieve top results in the competition of } \\
\text { women } \\
\text { - Establish the activity of professional } \\
\text { associations (trainers, managers, sports } \\
\text { medicine practitioners, sports scientists ...). } \\
\text { - Adopt a national standard and a workplace } \\
\text { framework in sport. } \\
\text { - Make healthcare available and compulsory. } \\
\text { - Develop the principles of career management } \\
\text { and post-career of athletes. } \\
\text { - Prepare tools for controlling training and } \\
\text { preparation programs. } \\
\text { - Establish the flow of information. } \\
\text { Work on the role model in the promotion of } \\
\text { women's sport }\end{array}$ & $\begin{array}{l}\text { - No activity is registered on the formation of } \\
\text { professional associations (trainers, managers, sports } \\
\text { medicine practitioners, sports scientists ...). } \\
\text { - Healthcare is available to all athletes. } \\
\text { - Prepare tools for controlling training and } \\
\text { preparation programs. } \\
\text { - Establish a database and information flow. } \\
\text { - Work on the role model in the promotion of } \\
\text { women's sport. } \\
\text { - Systemically intervene in the new statutes of the } \\
\text { NSO (during the harmonization with the New } \\
\text { Law on Sports), as well as on the programming } \\
\text { frameworks that the NSO will nominate through the } \\
\text { OCS and SSS. }\end{array}$ \\
\hline
\end{tabular}

The basics for state interventionism were set at the very beginning of state independence, due to the lack of knowledge or insufficient perseverance of the sport itself on Pan-European principles and directives concerning self-organization and the preservation of autonomy and specificity of sport. In 2006, during the preparations for a new - old political order, but a new social environment, there was no study of the place and role of sports in the direction of social progress. As most post-communist countries, which had recently changed their constitutions, so did Serbia, the sport and physical activity of citizens were entered into the Constitution (2006). As much as the constitutional category provides security for the conduct of sports in one country, it automatically includes specific legislation made by the state and is related to sport (Petry, Steinbach, Tokarski, 2004). That the Constitution was not a conditio sine qua non of the sport could be learned from the analysis of the Yugoslav past, but also from the Council of Europe documents (Chaker, 2004), or from PanEuropean practice in the presence of public authorities and laws in the conduct of sports activities (Carrard, 2006). The autonomous and affirmed national sports system, and not its constitutional category, determines the success of sports in Finland, France, Germany, the Netherlands, Great Britain, and Slovenia (Chaker, 1999). Some would say that this is an Anglo-Saxon approach to this matter. In 
other words, in an effort to name sport as a constitutional category, we have received a series of legal and sublegal documents that strengthen the state's jurisdiction in sports. With the Law on Sport (2016), the state moved from the subsidiary to the leading authority of Serbian sport. Therefore, what has been done around the sport as a constitutional category, can be qualified today as a sufficiently ruthless activity, premeditated or intentional, which was not harmonized with the democratic character of the society and the political system, which has become a weak link for the affirmation of the autonomous system of sport. This decision can be described in more detail by the effects produced:

\section{The absence of a consolidated sport manage-} ment, or some kind of consolidation of the sports system was done in the favour of politics. At this point, it should be emphasized that the consolidation of the system is done in order to achieve the essential goals of sport, and it is preserving the internal structures of the autonomous functioning of sports in its action towards politics. It strives once for a "strong voice" that will represent the sport, since according to the Charter on Sports of the Council of Europe, sport and the state are in a complementary relationship, not in relation of the superposition of the state over sports. Analyses of sports and government documents, as well as statements by sports officials of Serbia point out that the sports system has sought to consolidate (by 2009), and then, pressed by legal solutions, this place would be given to the state administration and its formal and informal representatives. It would important for sports historians to determine the circumstances under which this has happened, but for analysts of the sports system it is more important how it was done. Where did the system of sports "catch up" and how it did not notice what was going to be done to it? There were many "signs along the way", but sport did not know it or did not want to track and read them or was perhaps scared of the result?! It remains to be noted that during the public debate of the first Law on Sport of state-independent Serbia, only two sports organizations were publicly announced in 2009, namely the Olympic Committee of Serbia (OKS) and the Football Association of Belgrade. The then minister of youth and sport on the remarks of the Serbian Orthodox Church on the proposal of the law said: "By this law, we (comment by the author: read: the state), introduce the OCS into the Serbian sports system". The current law (referring to the Law on Sport of 1996) does not mention the OCS at all, so formally they are not a part of the sports system. The Minister continues: "In the new draft of the law, the OCS is respected very much and mentioned 16 times.... What may be confusing about the OCS is the place of that institution in the Serbian sport. They have ambitions to be, as they say, "the Serbian sports cap". It is not logical; it is not possible! What is explicit and important in this law is that no one is a "cap of sport" except that at the top of the sports pyramid there is the Ministry of Youth and Sports. This is logical, because the sport is largely financed from the state budget. And the Ministry relies on the non-governmental sector, branch sports federations, OCS and the Sports Union of Serbia" (Večernje novosti, June 7, 2009).

By analysing and illustrating this interview, it can be concluded that the decision on the issue of national sports regarding the consolidation and management of its system, passed by the Serbian Parliament, and at the proposal of a civil servant or party to which it belongs. Everything looked like communism cases during which sport was used for political purposes in which national sports organizations have consistently fought for the identity and autonomy of sports (Jeu, 1994). The National Olympic Committee is an independent sports organization that is conditio sine qua non of a modern state, even if it is the case in most EU countries. There are several cases of attempts to control the NOC by national governments in Africa, Latin America and Asia. On the other hand, there is a small number of European countries at the level of the ministry responsible for sport. The Olympic Committee of Serbia has existed since 1910, it is a sports organization that monitors the development of its society and its state. For more than a century, the OCS has become a "cultural institution" that has been leading the life of Serbian sports and Olympic traditions, and has always been the carrier of progress and the process of integrating Serbian society into modern societies of Europe and the world through sports and Olympics. 


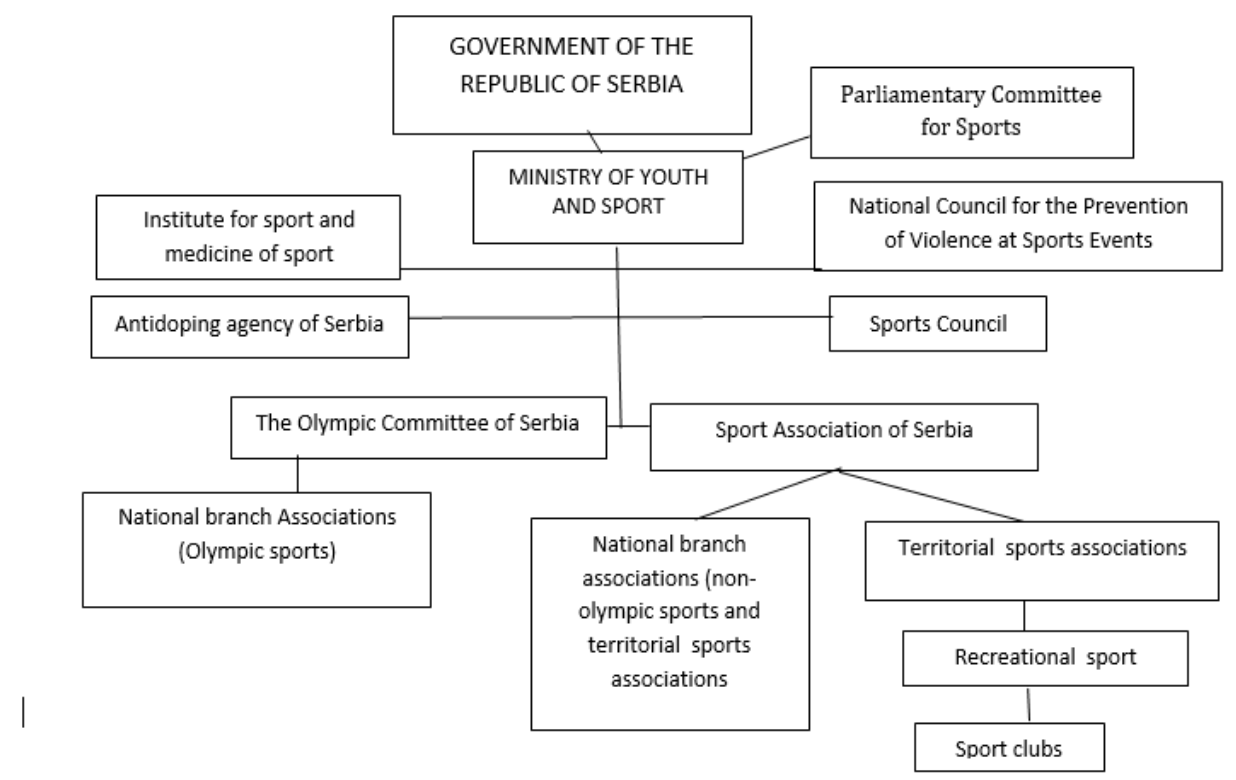

Chart 5 The sport system as seen by the Ministry of Youth and Sport (2013)

In order to make the discussion about the relationship between the NOC and the state clearer, one should know that the leading national sports organization describes five elements, its social identity, involvement in sport, orientation, organization and functioning, as well as its recognition (Slack, Parent, 2006). Nowhere in the world do governmental authorities in charge of sports have any attributes that could be recommended for participation in the sport system, even less in the management of its organization and operation. It is difficult to talk about the being of the ministry outside of the political, bureaucratic, technocratic, and partocratic one. The Ministry of Sport, if already existing as part of the organization of the state administration, in democratic societies acts through a horizontal network, more precisely a place in the environment of the sports system and at the macro level of sport organization. The Ministry of Sports is responsible for creating an environment for the development of sports in the country, through the implementation of the national strategy and coordination of the governmental and non-governmental sector Thus, the MOS in Serbia should, inter alia: (1) link the state administration system by acting according to state structures (Ministry of Finance - budget, games of chance, taxes, donations... Ministry of Science - scientific projects, research of the impact of sports on the population, Sustainable Development, Information Technologies and Information Society.... Ministry of Infrastructure - construction of sports facilities and their place in the development of cities and regions (Olympic and national training centres....; Ministry of Local Government - sport at the local level, concept, free the development and diligence of the facility, the priorities of local communities and the implementation of the state strategy in sports at the local level... Ministry of Education - integration of sports and physical education, educational function of sports, quality of physical education and school sports, school facilities as resources for children and youth sport.... Ministry of Health - sport and health, prevention, sports and medical protection system and health insurance of athletes...) There are close links between the activities of MOS and ministries of justice, defence, interior affairs, labour and social policy, foreign affairs... as well as within the scope of construction the environment of the sports system, as well as in the part of the participation in the sports system itself (military and sport in the police). (2) Participants in the development and regulation of a comprehensive sports system participate with the elements of the sports system itself (NSO, OCS, SSS...) (Jevtić, 2010).

The issues of financing sports by the state were imposed as a "crowning" argument in winning the leadership position on the Serbian sports pyramid. How much and how funding sports in Serbia is discussed in detail by the analysis of the Belgrade Institute of Economics which showed that in 2011 "the sport in Serbia lost 79 million euros a year due to the existence of a "black market for games of chance". The amount of financing sport by a state (central and local) is 
about 80 million euros. Due to the statutory choking of the voluntary sport organization and the lack of evaluation of volunteer work in sport, in Serbia, according to the same analysis, almost 200 million Euros of indirect participation in financing sports and the development of Serbian society are not identified "(source MOS, www.mos.gov.org.rs/analize ). The lack of organization of commercial and private sports, public-private partnerships and the definition of a part of sports as an economic activity..., there is a lack of recognition of the sports industry (Jevtić, 2014), which is highly quoted in the space of economic activity in the world (more than $4 \%$ of annual wealth of the world is realized through sports). Of course, for the full truth about the flows of sports financing, the address is not MOS, but Eurostat data, as shown for all EU countries. So, in Europe, as in the United States and around the world, the family is the one who participates in more than $50 \%$ in direct financing of sports. It is estimated that each family annually allocates up to $4 \%$ of its budget for the participation of its members, primarily children in sports, of which nearly $60 \%$ are spent on the purchase of equipment, equipment and footwear. In other words, when all indirect and direct sources of sports financing are gathered, the central state and the local community, according to Eurostat, directly finance sports with less than $30 \%$. In particular, according to a study from the College of Sport from Cologne (2011), for the whole of the European Union (27 countries) in 2008, the total budget amounted to 182.2 billion euros and contained direct benefits to the sport in the amount of 71.7 billion euros, 28.2 billion the estimated value of volunteer work in sport while 82.1 billion euros was spent by families for the purchase of equipment, apparatus, sports footwear and the like ${ }^{4)}$.

In the case of Germany, the central government invests around 360 million euros in sports per year (4-4.5 euros per capita) while almost 1 billion eu-

\footnotetext{
4) Participation in the direct costs of sport of 71.7 billion euros of the EU state budget belongs to:

- 40.4 billion or $56.3 \%$ of the home budget

- 23.4 billion or $32.6 \%$ of local community units

- 5.3 billion or $7.4 \%$ of the central government, of which 2.1 billion or $40 \%$ are from lottery, betting and games of chance

- 1.6 billion or about $2.2 \%$ sponsorship and donations of business-companies

- 0.5 billion or $0.7 \%$ of media rights

- billion or $2.2 \%$ of lottery, betting and games of chance, of which $90 \%$ is passed through the state budget, and some $10 \%$ are distributed directly to sports organizations

- 400 million euros from others, including EU funds.
}

ros is deducted from the sales of goods and services in sports (Breuer, 2009). There is no analysis of the refund of money through the value added tax from sport of Serbia. In practice, this return in Serbia is up to $70 \%$ of the money invested by the central government and local self-governments. What is the return on the investment of parents, sponsors, international sports organizations, economies, consortia, sports tourism, organization of sporting events... or how much is a wilful denial of revenue from lottery, betting and gaming, different tax and fiscal policies in favour of sport, this can be approximated by the example of Germany or any of the $28 \mathrm{EU}$ countries, and conclude that sport creates an added value for the society, which in the case of Serbia does not transparently return to the sport area as a proven and affirmed asset for educating young people, health of the nation, promotion of the state....

2. The interventionist type of sports legislation is an expression of the existing state regulation, political ideology and the degree of democracy of the society in which we live. Between the decentralized model, which is financed by local and regional authorities, we live in Serbia with the prerogatives of a strong central state. For example, Italy has a sports law (from 1947) with the NOC at the top of the sports pyramid, it does not pose a problem for it to be decentralized in sport management and to finance sports from local and regional sources. In the preparation of the Law on Sport in Serbia, out of the two possible sub models of state interventionism (legislative and financial), the legislator chose both, because he obviously estimated that only this way, in full, he can determine and limit the structure, organization, function, independence... of the sport system. It is obvious that the pro-European practice of continuously providing financial and logistical support to sport was not a sufficiently challenging ambition for the state and individuals from the politics in Serbia. They are also directed at the governing side of sport. In other words, in the area of legal regulation of sport, Germany, the Netherlands or the United Kingdom did not have a specific sport law, or Italy, Austria or Switzerland, which made the demarcation of powers between the sports and the central and state at the local level by the constitutions (Chaker, 2004), that is, the Czech Republic, which has opted for the non-interventionist sports law. What was done in Serbia is only seemingly similar to the decisions of the former communist countries and new EU members (Hungary, Croatia, 
Lithuania, Romania...). What distinguishes us from the eastern and western countries of the continent, but also the environment is the absence of a leader in the management of the NSS. The practice of organizing and functioning of the sports system is known as a consolidated model in favour of one leader at the top of the sports pyramid. Most often, this is a sports or NOC advice, as is done in France, Croatia, Italy, Slovenia. The second is a confederal model for consolidating the management of the sport system. In this model, sport is run by the Leadership Territorial Sports Organization and the National Olympic Committee. This is a model that is affirmed in the solutions of Germany, Sweden, Denmark.

3. Fragmentation of the sports system. The epilogue of the interventionist nature of legislation is also the process of disintegration of the whole system of sport. The sports system of Serbia today describes the absence of the organizational and management top of the sports pyramid in more than 160 national sports organizations. The process of registering new NSOs continues and takes place through the state administration according to which the original competencies of sport, such as recognition, registration and membership in its "virtual system of sports," have been moved. The theory of organization was inferred in Serbia, because recognition and management are an important part of the sport, while management bodies are compiled in that way to fulfil the mission of the organization within the environment in which the organization operates.

\section{CONCLUSION}

An analysis of the sports system is a complex process that is mainly carried out using qualitative research methods. Methods of research from process sociology and management in sport are used to describe the phenomenon, discover connections and form conclusions. The sport system is also analysed through the methodology of science dealing with society and its dynamics.

To the conclusions of the subject of this paper, which has been a system of sports in Serbia since 2006 , since the day of state independence to date, has been inductively deductive cognitive path, document analysis and reflection on a number of facts and challenges that have followed and influenced the flow of NSS changes.

It can be concluded that the system of sports in Serbia is not systematic, that is centralized, not autonomous, and that it is highly dependent on the state. It is not democratic, but under the constant influence of factors that do not belong to the sport system. It is financially not solvent, it lost its volunteer, it does not make significant progress in mass, reduced the number of athletes and sports branches that manage to qualify and perform at the Olympic Games. Significant participation of athletes in delegations for the Olympic Games and other multisport events has been recorded.

Although it was not the subject of this analysis, however, the analysed period also contains facts about the weakness of the sports system and at work:

- international sports cooperation, whereby the reception of the so-called "Kosovo" in the IOC and the international sports organization points out that our rules of international sports and relations prevail, so this reception can be considered as an epilogue of the absence of internal consensus, the mixing of politics in sports, the lack of strategy, inertia of individuals as well as entire organizations, non-incitement and / or interference in dealing with this problem at a time that could be considered opportune to resolve it (concluding with the London Olympics);

- a professional sport belonging to sports clubs that are not financially solvent while the allocation for participation in the league competitions is not in the function of preparing and participating athletes of these clubs in top amateur sport, including participation in the Olympic Games;

- commercial sport, private sport, university sport, public-private partnership in sports... are not in the agenda for the third decade of this century.

The sports system in Serbia has no leader. The state and politics have "entered" into a sport where, from the superposition of financial, legislative and political power, they act on factors and actors of sport, therefore, sport continues to seek for its value, organizational, program and managerial identity. Changes that were planned and partially realized and expected to lead to a Pan-European model of sport have "shifted" from the path of thoughtful and innovative development to the path of exhaustive and unprogressive state interventionism of unknown outcomes. 


\section{REFERENCES}

1. Bergsgard, A.N.; Houlihan, B.; Mangset, P.; Nodland, I.S.\& Rommetvedt, H. (2007). Sport Policy, A Comparative Analysis of Stability and Change. Singapore: Elsevier.

2. Blouce, D.\& Smith, A. (2010). Sport policy and Developement. London: Routledge.

3. Breuer, C. (2009). Sport Development Report 2007/2008, Analysis of the sports clubs, situation in Germany. Bonn: Bundesinstitut für Sportwissenschaft, Medienhaus Plump, Rheinbreitbach.

4. Camy, J.\& Robinson, 1. (2007). Managing Olympic Sport Organizations. Lausanne: Olympic Solidarity and Human Kinetics. Champaign, IL

5. Carrard, F. (2006). Autonomy of sport, comments. In R. Mitchell and P. Baummann Rapporteurs: First Seminar on the Autonomy of the Olympic and Sports Movement. Lausanne: International Olympic Committee.

6. Chaker, N.A. (1999). Study on national sport legislation in Europe. Strasbourg: Council of Europe Publishing.

7. Chaker, N.A. (2004). Good Governance in Sport, A European Survey. Strasbourg: Council of Europe Publishing.

8. Chappelet, J.L; Bayle, E. (2005). Strategic and Performance Management of Olympic Sport Organisations. Champaigin, Il: Human Kinetics.

9. Chappelet, J.L. (2010). Autonomy of sport in Europe. Strasbourg: Council of Europe Publishing.

10. De Bosscher, V.; Bingham, J.; Shibil, S.; van Bottenburg, M.\& De Knop, P. (2008). The Global Sporting Arms Race. An International Comparative Study on Sports, Policy Factores, Leading to International Sporting Success. Ltd.Oxford: Meyer\&Meyer Sport (UK)

11. De Senci, J (1990). Sport management circular evaluation and needs assessment: A multifaceted approach. J. of Sport Management 4: 31-58.

12. Deutsche Sporthochschule Köln (2011). Study on the funding of grassroots sports in the EU.

13. Digel, H. (2001). Talent identification and promotion. European Olympic Committee Technical Seminar Book, "Organisation of Talent Identification and Promotion", pp 10-29. Berlin.
14. Edwards, A.; Skinner, J. (2009). Qualitative research in Sport Management. Singapore: Elsevier, Ltd.

15. Evtič, B. (2013). Олимпийская программа в контексте развития системы национального спорта. [Olympic programs in the function of developing the national sports system. In Ukrainian ] Наука в олимпийском спорте, 1: 27-37.

16. Jevtić, B. (2010). Sistem sporta, sportski stručnjaci i bolonjski proces. [Sports system, sports experts and Bologna process. In Serbian]. In G. Kasum i sar. Angažovanost nastno-naučnog kadra sa akreditovanih državnih fakulteta sporta u okviru aktivnosti nacionalnih sportskih saveza $i$ eltinih klubova u stručnog kadra iz nacionalnog sporta $u$ sistemu obrazovanja i usavršavanja na akreditovanim sportkim državnim obrazovnim instirucijama. str.7-31. Beograd: Fakultet sporta i fizičkog vaspitanja i Ministarstvo omladine i sporta.

17. Jevtić, B. (2011) Refleksija menadžmenta olimpijskih programa na sistem sporta Srbije. [Reflection of the management of the Olympic programs on the Serbian sports system]. SportLogia 7 (2) 129-140, doi 105550 / sgia110702se129J

18. Jevtić, B. (2011a). Sistem sporta i dečiji sport. [A system of sports and children's sports. In Serbian] U B. Jevtić, J. Radojevič, I. Juhas, R. Ropret (Ed). Dečiji sport od prakse do akademske oblsti (str 6991). Beograd: Fakultet sporta i fizičkog vaspitanja.

19. Jevtić, B. (2011b) The Path of True Values. ACC Journal, Social Science and Economy. XVII : II 8287

20. Jevtić, B. (2011v). Žena u programima OKS iskustva prethodnog i strategija olimpijskog ciklusa 2008-2012. [Woman in NOC of Serbia programs - experience of the previous and strategies of the Olympic cycle 2008-2012.] Fizička kultura 65(c1): 29-41.

21. Jevtić, B. (2012) Upravljanje programima za učešće na mega sportskom događaju. [Management of programs for participation in mega sports event.]. Management, 63: 63-75.

22. Jevtić, B. (2014). Sport and enterpreneurship. In Proceedings "Techology, Culture and Development”, pp 122-134, Belgrade. Asosciation Technlogy and Society. 
23. Jevtić, B. (2017). Naučni časopis "Fizička kultura" u misiji razvoja naučne i društvene zajednice. [Scientific journal "Physical Culture" in the mission of scientific and social community development]. Fizička kultura 71(2), 182-194.

24. Jeu, B. (1994). Sports and Social and Cultural Phenomenon. In "For Humanism of Sport", Ed of. Comite National Olympique et Sportif Francais, Paris.

25. Kay, T. (2012) Accounting for legacy: monitoring and evaluation in sport in development relationships, Sport in Society, 15:6, 888-904, doi: 10.1080/17430437.2012.708289

26. Loland, S. (2009) The Ethics of PerformanceEnhancing Technology in Sport, Journal of the Philosophy of Sport, 36:2, 152-161, doi: 10.1080/00948705.2009.9714754

27. Mrkonjic, M. (2013). Sports organisations, autonomy and good governance. Working paper for Action for Good Governance in International Sports Organisations, (AGGIS) project.

$28 . \quad$ https://www.researchgate.net/publication/323696569

29. Petry, K., Steinbach, D., \& Tokarski, W. (2004). Sport systems in the countries of the European Union: Similarities and differences. European Journal for Sport and Society, 1(1), 15-21.

30. Slack, T., Parant, M.M. (2006). Understuding Sport Organization: The Application of Organization Theory. Champaigin, Il:Human Kinetics.

31. Vukašinović, V. (2018). Vladan Đorđević, život i delo vežbača, naučnika, političara, književnika, utemeljivača srpske gimnastike i sokolstva. [Vladan Đorđević, the life and work of a gymnast, scientist, politician, writer and the progenitor of gymnastics and the Sokol Movement in Serbia]. Fizička kultura, 72(1), 5-19

32. Radojević. J., Jevtić, B. (2011). Društvo i sport dece i omladine. [Society and sport of children and youth. In Serbian]. U B. Jevtić, J. Radojevič, I. Juhas, R. Ropret (Ed). Dečiji sport od prakse do akademske oblsti (str 31-44). Beograd: Fakultet sporta i fizičkog vaspitanja.

33. Šuput, D. (2015). Nastajanje sportskog prava Evropske unije. [The emergence of EU sport law.]. Strani Pravni Život, 2:99-115.

\section{Documents}

1. Jevtić, B. (2006). Idejni okvir novog sistema sporta Republike Srbije. Zajednička sednica činilaca sistema sporta Srbije. [The conceptual framework of the new sports system of the Republic of Serbia. Joint session of the members of the Serbian sports system. In Serbian]. Beograd: Olimpijski komitet Srbije.

2. Jevtić, B. (2006-6). Projekat OKS "Peking 2008". [Project NOC of Serbia "Beijing 2008". In Serbian]. Beograd: Olimpijski komitet Srbije.

3. Jevtić, B. (2009). Projekat "Olimpijska Srbija". [Project NOC of Serbia "Olympic Serbia”. In Serbian]. Beograd: Olimpijski komitet Srbije.

4. Ministarstvo omladine i sporta (2008). Nacionalna strategija razvoja sporta u Republici Srbiji (2009-2013 i 2013-2018) [National Strategy for the Development of Sport in the Republic of Serbia, 2009-2013 and 2013-2018. In Serbian]. www. mos.gov.rs

5. Jevtić, B., Manojlović, P. (2014). Finalni dokumet sa akcionim planom u oblasti vrhunskog i profesionalnaog sporta i medjunarodne sportske saradnje. [Final document with Action plan in the field of top and professional sports and international sports cooperation. In Serbian]. Beograd: Olimpijski komitet Srbije.

6. European Council (2000) Declaration on the Specific Characteristics of Sport and Its Social Function in Europe.

7. European Commission (2007) White Paper on Sport.

8. European Commission (2011) Developing the European dimension in sport.

9. Council of Europe (1992). European Sports Charter.

10. United Nations (2000). Controbution of Sport to the Millennium development goals (www.un.org/ sport/sites/www.un.org.sport/files/documents/ pdfs/). 


\title{
СИСТЕМ СПОРТАУ ДРЖАВНО НЕЗАВИСНОЈ РЕПУБЛИЦИ СРБИЈИ - ОД ПРОМИШЪЕНОГ ПОЧЕТКА ДО ИСЦРПЉУЈУЋЕГ ДРЖАВНОГ ИНТЕРВЕНЦИОНИЗМА
}

\author{
Бранислав Јевтић \\ Факултет спорта и физичког васпитања, Универзитет у Београду, Србија
}

\begin{abstract}
Сажетак
Предмет овог рада су промене у националном систему спорта (НСС) које трају од пуне државне независности Републике Србије (од маја 2006. године) до данас. Националне спортске организације су биле те које су иницирале промене које су се тицале како спорта тако и укупне културе и науке о физичкој активности. Промене су започете са веровањем да ће исте бити целисходне развоју спорта и друштва у Србији. Документа садрже чињенице о стремљењу лидера тог времена ка консолидованом моделу спорта, утемељеном на његовој широкој аутономији. Планирано је да се промене одвијају уз логистичку и финансијску помоћ актера ван самог система спорта, укључујући и државу (централну и јединице локалне самоуправе). У ограниченим околностима друштвено-економског развоја и политичког система Србије, промене су се одвијале и уз учешће државе, при чему се региструје њена подршка (2006-2007), партнерство (2008-2010), да би од 2011. године, била успостављена политичка, а потом и правна (законска) „консолидација“ националног спорта у корист државе - политике. Све што је учињено од маја 2006. године у систему спорта у Србији се може вредновати у односу на различите критеријуме, пре свега, у односу на резултате спортиста, али и односу на: организацију великих појединачних и мултиспортских такмичења; развој појединих области од значаја за афирмацију и хуманизацију националног спорта (спортско-медицинска заштита спортиста, анти-допинг, параолимпијски спорт, учешће жене у спорту....); издвајање за спорт; учешће грађана у физичкој активности и масовност спорта... али и кроз критеријум управљања и консолидације система спорта и утицаја државе и политике на спорт. У односу на последњи наведени критеријум, у овом раду је сагледан његов ток и епилог на НСС. Закључак је да систем спорта и даље трага за својим вредносним, организационим, програмским и управљачким идентитетом, као и да су промене система спорта у Србији „скренуле“ од промишљеног и иновативног почетка ка исцрпљујућем и необећавајућем државном интервенционизму непознатог исхода!
\end{abstract}

КљУчНе речИ: НАЦИОНАЛНИ СИСТЕМ СПОРТА / УРПРАВЉАҢЕ / ДРЖАВНИ ИНТЕРВЕНЦИОНИЗАМ / АУТОНОМИЈА И СПЕЦИФИЧНОСТ СПОРТА / СРБИЈА 


\section{УВОД}

Заједничи именитељ сваке државе у 21. веку су њени симболи (застава, химна...), њена културна особеност, одрживи развој, али и национални систем спорта (НСС) којим се стварају системске претпоставке како за развој самог спорта, тако и за трансфер многобројних вредности спорта према прогресу друштва и сваког његовог члана (Blouce, Smith, 2010).

Нације не стварају победнике, оне нису ни победничке ни губитничке. Свака од нација тежи систему - „Светом Гралу“ којим ће афирмисати васпитно и вредносно у спорту и којим ће креирати услове за успех појединца и тимова на међународним такмичењима. Постало је очито да се критеријуми за вредновање једног НСС морају успоставити у односу на јединство његових чинилаца, подели улога и задужења, кадрова, организационог оквира... Тенденције које се региструју код НСС-а су и сталне анализе које воде до избора ефикаснијих метода и садржаја у стратегији остваривања националне и интернационалне мисије спорта. А она, ми= сија спорта у 21. веку је напредак друштва и сваког појединца кроз учешће у спорту (од учесничког до врхунског и елитног спорта), због чега је спорт постао део део културне вредности и особености друштва коме припада и унутар кога се обликује и гради НСС као систем могућности да се сви грађани, регије и области баве спортом. Поред тога, НСС подразумева организационо и функционално повезивање великог броја чинилаца према прокламованим правцима деловања спортског и олимпијског покрета. Другим речима, НСС садржи и подразумева испуњавање унутрашњих чинилаца спорта и његовог окружења, због чега се и успоставља и развија око културне, историјске и економске особености друштва коме припада, односно, мора да испуни спољашне критеријуме за учешће у структурисаном и препознатом спортском и олимпијском покрету (Евтич, 2013).

Сваки од НСС-а се ослоњају на три стуба. Први стуб је друштво коме тај систем припада. Други стуб гради структура самог система, док је трећи стуб испуњен актерима из окружења самог спорта и његовог националног система (De Bosscher, Bingham, Shibil, van Bottenberg, De Knopp, 2008).
Како има утемељење у вредносно-културном бићу друштва коме припада (први стуб), стога, када се дешавају промене целине или делова целине система спорта (други стуб), тада се постављају и многа питања о току и исходима промена, као што су: „интензитет промена (брзина промена и њихов одвијање као еволуција или револуција) значај промена, нове организационе и управљачке структуре, реалистичност и остваривост прокламованих циљева, ангажовање унутрашњих ресурса спорта, начину руковођења, динамици и обиму организационих промена, карактеру и ефикасности администрације, статусу волонтера, очекивањима актера и њихових чланова, и слично“ (Camy, Robinson, 2007).

Промене система не подразумевају само промену организационих и управљачких целина спорта, већ, и пре свега, промену његове вредносне оријентације и културног контекста и одвијају се у складу са економском моћи друштва (Bergsgard, Holihan, Mangset, Nodland, Rommetvedt, 2007). Другим речима, промене НCC су комплексан вишегодишњи процес који се планира и реализује применом квалитативних метода и техника из процесне социологије (Edwards, Skinner, 2009) - анализа процеса управљања и менаџмента у спорту - опис феномена, откривање веза, као и формирање закључака о систему спорта као предмету будућих промена (Jevtić, 2011a). У складу са наведеним, али и нешто шире, ван контекста овог рада, треба посматрати и промене система спорта у Србији (предмет овог рада) које се одвијају од 2006. године, од првих дана њене пуне државне независности. О циљевима и правцима ових промена се може више сазнати из неколико документа која су усвојена на нивоу система спорта, доминантно на Националном олимпијском комитету (НОК), односно кроз два закона о спорту (2009 и 2016) и две стратегије спорта које су као докумената Владе Републике Србије усвојене 2009. и 2013. године.

У првом месецу државне независности Србије усвојена је заједничка платформа представника тадашњег система спорта и Владе Републике Србије, која је кроз документ „Идејни оквир новог система спорта Србије“, отворила процес промена и створила основе за организациону и функционалну евалуацију, а потом и еволуцију дотадашњег система спорта - "Идејни оквир садржи везе који су засноване на потребама 
спортиста и грађана, спортској традицији, утицају националних и интернационалних чинилаца на развој спорта...” између осталог стоји у Записнику са овог Скупа (Јевтић, 20116). Усвојеним оквиром су назначени правци да систем спорта функционише по моделу спорта свих грађана, односно на основама „зрелог“ система учесничког спорта. У том правцу, као приоритети даљег развоја су издвојени дечији и омладински спорт као предворје за целоживотно бављење физичком активношћу и стицање здравих животних навика, али и као улазак у врхунски и елитни спорт (освајање медаља на ОИ, СП, ЕП) и очување међународне конкурентности резултата. Оквир је дефинисао укљученост државе у уређењу окружења спорта, одредио ниво централизације, док је за управљање спортом предвиђена координација између Савета за спорт (кога је требало основати), Олимпијског комитета Србије и Спортског савеза Србије, као територијалне националне спортске организације. Другим речима, било је предвиђено да се управљање системом спорта у Србији одвија кроз конфедерални модел, као што је то у Немачкој и земљама Скандинавије. Као и сваки документ са овом и сличном проблематиком, тако је и овим документом истакнута неопхнодност очувања аутономије и поштовања специфичности српског спортског покрета. Оквир недвосмислно садржи раскид са праксом организовања и управљања спортом из последњих декада 20. века. Ипак, као и сваки други идејни документ, тако ни овај Оквир није имао капацитет, али ни мандат да у целости уреди систем спорта, тако да су питања, а пре свих она која се тичу објеката за тренинг и такмичење, финансирање спорта, као и спорт у општинама и градовима (локални ниво), регионима, главном граду..., место и улога државе..., остала да се разраде кроз националну стратегију спорта и да се преточе у адекватна документа свих актера спорта и његовог окружења! Оквир је имао за циљ „долазак“ до ефикасног модела система спорта, да тајпут тече крозприменунаукекакоунепосредном тренингу тако и спортском организовању, и у том правцу је препознат Факултет спорта и физичког васпитања Универзитета у Београду као националне институције која је кадра да преузме задатке научног развоја и да кроз своје катедре и друге организационе јединице (одељења) буде покретач чланица и целине система спорта Србије ка променама (Јевтић, 2010).
Унутар две стратегије развоја спорта, које су усвојене као документа Владе Републике Србије, записано је да су оба настала као израз, али и као потреба креирања оних активности којима би се дала подршка вредносним и организационим аспирацијама спорта, пре свега оним које се односе на: (1) што веће учешће грађана свих узраста (учеснички - масовни спорт), (2) креирање услова за хумано одрастање деце кроз спорт (дечији спорт), (3) постизање и одржавање врхунских и елитних спортских резултата (врхунски спорт) (Национална стратегија, 2009, 2013). На жалост, систему спорта у Србији хронично недостају документа вишег сазнајног нивоа, организационог, вредносног, утилитарног... оквира, сачињених на чињеницама до којих се стиже научним приступом у процесу сазнања и управљању променама. И поред чињенице да у Србији ради десетак факултета спорта и два завода за спорт, да је, дакле бројна и респектабилна академска заједница, ипак, она као да не жели или није кадра да препозна потребе спорта, самим тиме ни српског друштва. Другим речима, недостају изучавања која би довела до динамичнијег развоја НСС заснованог на чињеницама које су проверене у најбољој пракси и потврђене методама научног сазанања. Трећа мисија универзитета у простору спорта се не остварује (Јевтић, 2017).

\section{О СИСТЕМУ СПОРТА СРБИЈЕ}

\section{I}

Република Србија је државно независна од маја 2006. године. Ипак, са променама система спорта се отпочело знатно раније, непосредно након политичких промена из октобра 2000. године. Промене система спорта су се доминантно одвијале кроз активности НОК и кроз пројекте као што су: доопремање Републичког завода за спорт, Музеј спорта и олимпизма, кандидовање за организацију Европског олимпијског фестивала младих (енг. ЕYОF), организација националних и међународних конференција и семинара. Национални олимпијски комитет је био усмерен и ка чланству у спортским телима 
Савета Европе (енг. EPAS), Европској невладиној спортској организацији (енг. ENGSO). Није се „одрицао“ учешћа у програмима MOK-а кроз које су студенти из Србије боравили у Олимпији, и кроз које су се неки од кадрова спорта Србије школовали кроз мастер студије менаџмента спортске организације (енг. MEMOS). Тадашњи НОК је реализовао и програме дечијег спорта, афирмације жене у спорту, екологије и културе кроз спорт...
И поред значајног броја програма и активности НОК-а, ипак то није било ни изблиза довољно да се гради ефикасан и савремен НСС, да се реше проблеми, као што су кадрови и велики број наслеђених проблема, изазова и недоумица (Табела 1). Свака од спортских организација, као и свако од занимања укључених у рад система спорта констатовали су проблеме и застој у области свог деловања и надлежности.

Табела 1 Елементи националног система спорта као основа за развој спорта и спортских грана (Digel, 2001).

$$
\begin{aligned}
& \text { - историјске околности и олимпијска традиција } \\
& \text { - идеолошка заснованост } \\
& \text { - заинтересованост за врхунски спорт } \\
& \text { - организационе структуре система } \\
& \text { - структура особља (запослени и волонтери) } \\
& \text { - финансије } \\
& \text { - спортисти } \\
& \text { - тренери } \\
& \text { - идентификација талената } \\
& \text { - промоција талента } \\
& \text { - технологија тренинга }
\end{aligned}
$$

Детектовани проблеми унутар система спорта у Србији, те 2006. године нису били мали. Исти су процењени ограничавајућим на укупан развој спорта, како у врхунском, тако и на нивоу учесничког спорта, односно, они су детектовани како на нивоу националне спортске организације (НСО), тако и на нивоу спортског клуба (Јевтић, 2006, 2006а). Стога, и поред најбоље жеље да сви проблеми спорта буду решени што пре, ипак, рационалним приступом кроз каузалну, функционалну и анализу потреба и могућности, одређени су приоритети и именоване активности које треба да воде ка прогресу система. Међу њима, на првом месту, нашли су се избор „вредносног компаса“ за будући НСС, дефинисање приоритета, избор активности за које је процењено да ће довести до еволутивних промена без успоравања самог спорта (тренинга

$$
\begin{aligned}
& \text { - систем такмичења } \\
& \text { - спортски објекти } \\
& \text { - систем награђивања спортиста } \\
& \text { - систем награђивања тренера } \\
& \text { - друштвена сигурност за спортисте } \\
& \text { - друштвена сигурност за тренере } \\
& \text { - спортско-медицинска контрола и заштита } \\
& \text { - борба против допинга } \\
& \text { - приоритети у развоју } \\
& \text { - трендови у развоју спорта } \\
& \text { - специфични национални интереси }
\end{aligned}
$$

и такмичења)“ (Јевтић, 2010). На почетку промена мало се знало о интенцијама у развоју српског друштва, самим тиме било је отежавајуће планирати развој националног спорта без сазнања о општим и посебним агендама развоја многобројних друштвених актера и система. Како за спорт, али тако и за друге области друштва, заједничко је било, можда и остало, хронично одсуство системског и систематског праћења промена и усмеравање актера друштвене стварности ка вишим циљевима и ефикасним нивоима организовања и демократије. Стога, треба нагласити да, и поред десетине академских институција у простору науке о физичком васпитању и спорту, изучавања НСС је реткост. Хотимично или не, тиме су многобројни видљиви и решиви проблеми спорта, временом постали „нерешиви“ и преведени у његову „потиснуту 
реалност“, чиме је значајан део промена НСС одложен на неодређено!

\section{II}

Многобројне активности које прате промену система спорта у Србији своје корене имају у „визионарству спортских заљубљеника и ерудита за просперитет грађана Краљевине Србије“ (Вукашиновић, 2018) и вишедеценијском развоју спорта и физичке културе кроз југословенско друштво. Од новијих, из периода од јуна 2006. године треба још једном истаћи значај и правовременост „Идејног оквира новог система спорта Србије“ од кога се очекивало да подстакне и усмери промене НCС-a. До овог документа се дошло након вишестране анализе функционисања и анализе потреба система спорта Србије у новом спортском, друштвеном, политичком и међународном окружењу. Иако су можда неки очекивали да ће спорт показати неки вид отпора променама, ипак са истима је отпочело већ првих дана државне независности, и исте су се, доминантно одвијале око НОК-а. На жалост, плиткоћа система, долазећи спортски догађаји и проритетна оријентација према очувању конкурентности резултата српских спортиста (тимова и појединаца) одредила је да се са променама започне око питања врхунског спорта и његове две претпоставке: (a) спортиста - вежбач (биле су оријентисане према спортисти и његовим личним, социјалним и тренажно-процесим потребама, учињени су искораци ка спортоцентричној поставци система као једној од вредности спорта 21. века), (б) организациона, управљачка целисходност и професионализација односа између чинилаца система спорта, од спортског клуба до самог националног олимпијског комитета. Оно чега у овим првим активностима и корацима ка новом систему спорта нема, то је оно што недостаје и у данашњим агендама његовог развоја, а тиче се фундаменталних питања развоја српског друштва кроз спорт, као што су: организачије и управљьана спортом (управљања и независности НСС, управљање квалитетом спортске организације...), место и улога професија и занимана у спорту (афирмација занимања спортски тренер и нових професија у спорту...), каријера врхунских спортиста (социјална сигурност и каријера након спорта), до питања технологије тренинга (целисходност и ефикасност тренажнотакмичарског процеса; идентификација, детекција и развој талената за спорт; тренажни центри...). Поред ових, и даље се трага за начинима дестигматизције и ресоцијализације појединих група друштва кроз спорт. Разлог овим, као и другим програмским и системским редукцијама треба тражити, како у својеврсном „легату“ небављења и непрепознавања мисије спорта, али и у: (a) зачетнику промена и мисији његовог деловања (то је у овом случају био НОК, данас Олимпијски комитет Србије - ОКС); (б) поводу за промене (приоритетно око очувања конкурентности врхунског спортског резултата и припремама спортиста и делегације за учешће на Олимпијским играма у Пекингу, 2008), (в) историјском, економском, политичком... контексту друштвених промена које је донела државна независност; (г) навикама и очекивањима које су испуњавале односе и одређивале правце развоја спорта током периода социјализма; (д) недовољно познавање простора НСС, његове структуре и праваца промена; (ந) недостатак интерпретативног оквира за ново разумевање мисије спорта - у складу са потребама 21. века.... (e) „плиткоћа“ система кога прате и детерминишу ограничени вредносни, организациони, људски и технолошки ресурси, кадри да друштву и спорту испоруче стратешку парадигму која ће водити до нове националне стварности.

Сумирајући учињено, може се рећи да је НОК као зачетник промена одговорно приступио изазовима промене државног статуса Републике Србије у простору спорта. Изабрани пут деловања је одговарао принципима „дубинског поимана проблема“. Другим речима, учињено из тог периода, иако је било успостављено око програма за учешће на ОИ (Олимпијски програм - ОП), ипак, оно је било испуњено целовитим сагледавањем укупног проолиимпијског спорта, како у његовом технолошком и резултатском смислу и значењу, организационом и научном усавршавању, тако и у социокултурном контексту деловања спортом на промене српског друштва (Схема 1). Иако је у решавању проблема и изазова спорта могао прићи са релативистичке стране (норме и критеријуми за учешће на такмичењима као једини критеријум), ипак, поштујући контекст савремене националне спортске организације 
(HCO), потреба спорта и самих спортиста, ОКС се определио за стратегију природног напретка (прогрес у већем броју области којима се гради целовити систем националног и проолиимпијског спорта као аксиом националног спорта), чиме је учинио дубински приступ националном спорту, односно спорт је сагледао као: „иири контекст који је дубински повезан са социокултурним и моралним вредностима слободе и одговорности свих актера система спорта, пре свихспортиста, тренера, лидера спорта“" (Loland, 2009). Стога не треба да чуди да је и данашњи мото ОКС-а „Пут правих вредности“ израз ширег сагледавања мисије и аспирације ове водеће НСО да истраје на вредносном курсу развоја спорта и друштва Србије (www.oks.org.rs).

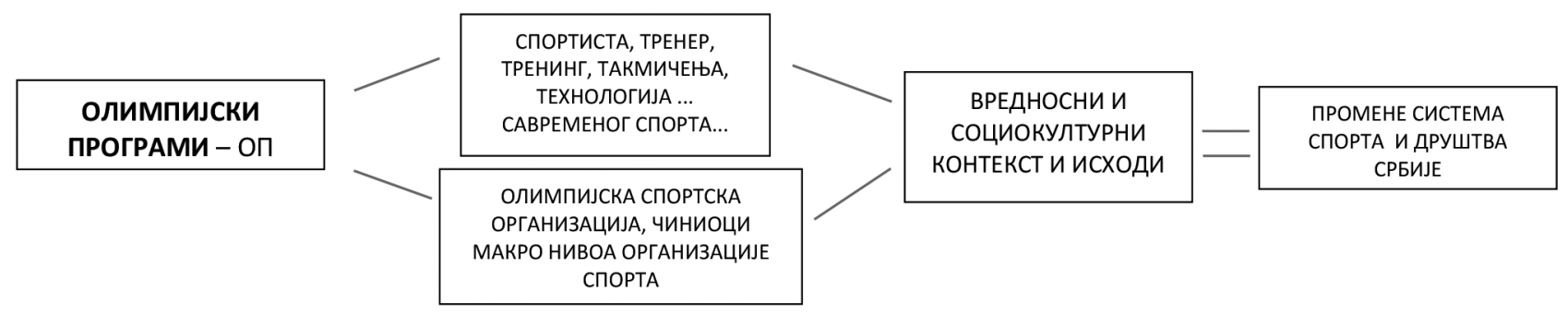

Схема 1 Олимпијски програми у контексту промена система спорта и друштва Србије

Иако се као непосредан циљ намеће припрема за учешће на олимпијским играма, ипак контекст ОП је шири и њима припадају: подстицање духовне и физичке хармоније појединца, његове аспирације према савршенству и постигнућу, неговање односа једнакости, пријатељства, толеранције, разумевања, заштита идентитета спортисте, тима, делегације, самог спорта и олимпизма, изградња преференци за такмичење и висок степен конкурентности, усавршавање окружења и његова ефикасност у сусретању преференци спортисте, социјална сигурност спортисте и нулта толеранција на допинг (Јевтић, 2011б,в).

\section{III}

Процесне, структурне и организационе анализе учињеног у систему спорта Србије упућују да су оне вођене слично, али и, у исто време и особено, дакле различито у односу на компаративне европске системе спорта (Евтич, 2013). Детаљнија анализа промена већине европских система спорта, оних који су са променама отпочели осамдесетих година XX века, указује да: промене трају дуже од једне деценије; променама се руководи из једног (консолидован модел) или више центара (не-консолидован модел); брига о спортисти се налази у центру промена; промене су повезане са политичком подршком која се најчешће развија око врхунског спорта; промене се одвијају кроз координацију ресурса, технологија, процеса, особља, као процес одлука и активности заснованих на испуњавању специфичних задатака (DeSienci 1990). Декаду касније, може се закључити да се систем спорта у државно независној Републици Србији, између осталог мењао по наводима Дисиенца, али и то да је интензитет тих промена био промењив и непредвидив, како по исходу на НСС, тако и на актере тих промена. Другим речима, могуће је утврдити неке особености у променама система спорта Србије, а за које се може рећи да нису биле добронамерне за његов будући статус, и које се, пре свега се односе на:

- одржавање навика из социјализма или и даље одржавање социјализма?, а што се огледа у очекивању самог спорта од давања државе;

- непостојање аутономних спортских тела која руководе системом спорта и која су задужена за планирање развоја, праћење и евалуацију учињеног у спорту;

- законско регулисање спорта (закони о спорту из 2009. и 2016.) које је у великом броју чланова у супротности са мисијом спорта и његовим паневропским трендовима и вредностима;

- одсуство легата српском спорту и друштву након организација међународних спортских такмичења; 
- непрепознавање и неуважавање европских конвенција и легислативе која се тиче спорта, сходно чему се региструје велики број проблема у поштовању специфичности спорта и чиме је директно угроженено одржање његове аутономије ${ }^{3)}$;

- усвајање стратешких документа развоја спорта на владином али не и на нивоу самог система спорта (владине стратегије развоја спорта 2009. и 2013);

- хронично присуство али и утицај политике која је временом добила обрисе мешања у унутрашња питања самог спорта и спортских грана;

- одсуство акционих планова за развој учесничког - масовног спорта, нарочито кроз повезивање са спортом у институцијама (школски спорт, спорт на универзитету, у полицији, војсци) и комерцијалним спортом;

- одсуство јасног дефинисања професионалног спорта и стварања претпоставки за његову афирмацију кроз одрживе спортско-финансијске токове;

- занемарену међународну спортску сарадњу.

Стиче се утисак да сам спорт, у првом кораку трагања за целовитошћу свог система и аутономним идентитетом, није препознао своје биће, да није уважио функцију која му је предодређена у овом веку, као и да није препознао структуру на којој се успоставља и гради национални спорт (Слика 1), због чега су спорт у институцијама и приватни спорт, остали ван контекста промена, самим тиме и ван целине система спорта који се и због овог разлога може именовати као „плитак“, несврсисходан, застарео, неинвентиван, пословно превазиђен и сл.

\footnotetext{
3) Принцип аутономије олимпијског и спортског покрета дефинисан је члановима Повеље МОК-а, статутима националних олимпијских комитета. Аутономија (право да слободно одреди правила по којима ће се појединци и организације владати и управљати без мешања спољних фактора) се брани и статутима међународних и националних спортских организација. Сва документа која се односе на аутономију спорта чине спортску законску регулативу (Lex sportive) олимпијског и спортског покрета. Права спорта и спортиста се штите на Суду спортске арбитраже (Court of Arbitration for Sport) као и правилима Светске антидопинг организације (WADA), која преко УН и Савета Европе, делује према чланицама у правцу „од допинга чистог спорта“(Suput, 2015). Односи у спорту су, у односу на пословање и комерционалне законе, регулисани Lex Mercatoria нормативом (Carrard, 2006).
}

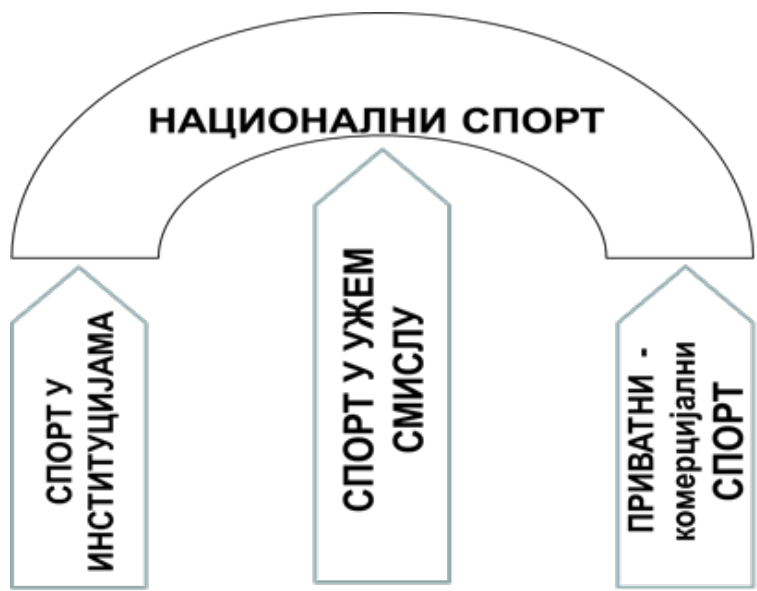

Слика 1 Стубови националног спорта

IV

Како је и претходним наводима истакнуто, сам спорт је у првим месецима државне независности Србије иницирао промене, међу којима је централна била она од које се очекивала консолидација самог система, а која је подразумевала вредносно и организационо обликовање уруковођењу спортом из самогспорта (поставка за консолидовани модел управљања спортом). Веровање о консолидацији било је могуће успоставити с'обзиром да су претходно јасно дефинисане три организационе целине нивоа новог система спорта Србије (микро, мезо и макро ниво, Схема 2). Сагледавајући из данашње перспективе, може се рећи да су промене, на самом почетку њиховог одвијања, биле на линији искустава већег броја европских система спорта о којима реферишу истраживачке и аналитичке студија (Bergsgard et al, 2007, De Bosscher et al, 2008). Тако се и у Србији, на првом или микро нивоу стремило решењу спорту инхерентних проблема, као што су брига о спортисти и континуалном одвијању квалитетног и ефикасног тренажног процеса. Од овог нивоа се очекивало да донесе одговоре и на питања занимања спортски тренер, као и друга афирмисана и нова занимања значајна за ефикасно и квалитетно одвијање спортске активности. Идејним оквиром из 2006. године је предвиђена национална тренерска организација која није успостављена ни до данас, тако да су сва стручна и питања овог занимања остала занемарена, док се са припремама за афирмацију професије спорт није ни започело, боље рећи не зна се ни ко то треба да обави! 


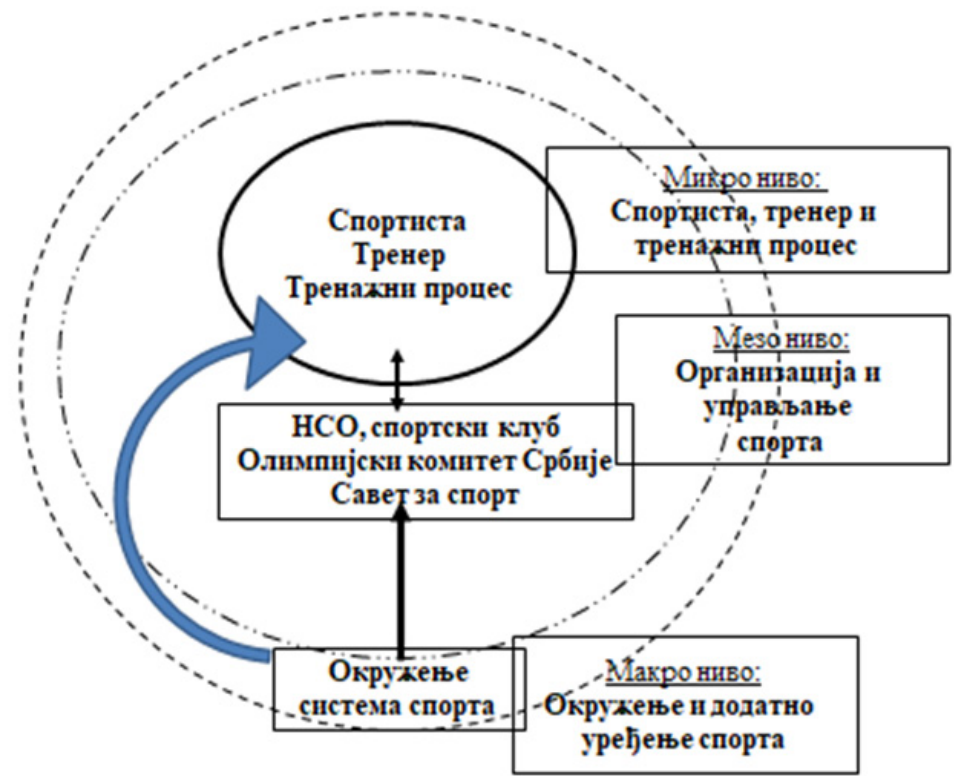

Схема 2 Нивои и чиниоци организације НСС

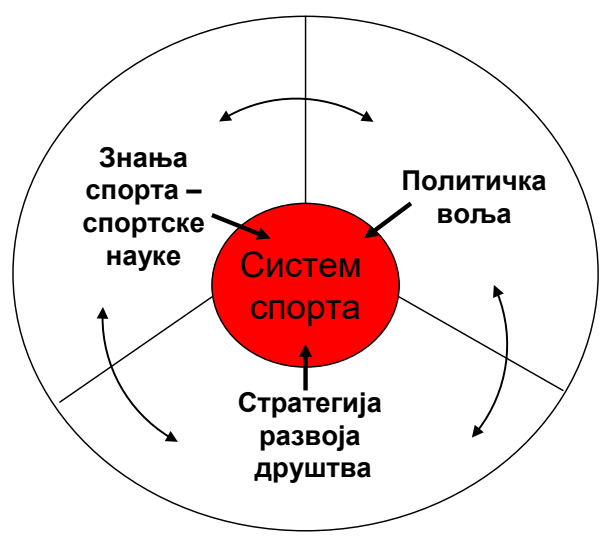

Схема 3 Фактори који одређују НСС
На другом или мезо нивоу, одвија се организација и управљање системом спорта. Један од циљева актера овог нивоа је настојање да се спорт повеже са комплементарним стратегијама развоја српског друштва (Схема 3). Веровало се да ће министарство задужено за спорт (Министарство омладине и спорта, МОС) радити на интеграцији друштва кроз спорт. Ово, данас може се рећи лаичко веровање није узело у обзир фактор политичког уређења, политичке воље и политичке културе, али ни пасивност наука (Схема 3). Поред тога, веровало се да ће се и у Србији, као и на нивоу Уједињених нација, спорт препознати као интегративни процес у реализацији циљева 21. века (Sport to the Millennium goals), односно да hе се промене НCC-а одвијати као и на почетку 20. века када је основан НОК (Олимпијски клуб Србије, 1912) и са идејом водиљом преузетом од МОК-а која проистиче из класичног либерализма и Локове теорије социјалног договора ${ }^{4}$. Србија је тада била на истом становишту као и МОК (основан 1896) и Светска фудбалска асоцијација (енг. FIFA основана 1904), ценили су да ће се бит аутономног спорта изгубити када се

\footnotetext{
4) У писму о толеранцији, Лок је сматрао да волонтерске организације имају право да самостално поставе своја правила и регулишу своје односе. Наспрам овом виђењу, у Србији као да је превагла Русоова теорија друштвеног договора која оставља мало простора за независне волонтерске организације.
}

појави „дивовска фигура опасне и непрецизне државе“(Chappelet, 2010).

Један од начина и средство који најефикасније може да повеже сва три нивоа и све чинииоце националног система спорта су спортске науке које, на жалост Србије, ни структуром али ни суштином нису прихваћене до данашњих дана. Нови студијски програми на Факултету спорта и физичког васпитања Универзитета у Београду из 2005. године нису довољно дуго трајали да би се могао евалуирати њихов ефекат на систем спорта и афирмацију спортских наука као кровне научне области (трајао је од 2005-2008). Овој, научној аспирацији самог спорта предвођеног НОК-ом може се приписати доопремање и афирмација улоге Републичког и покрајинских завода за спорт. Данас се може закључити да је на мезо нивоу остао нерешен велики број проблема, пре свега оних који се односе не функционисање спортске организације како у спортском, тако и у пословном контексту. Већина спортских организација, ни данас, није кадра да креира визију свог развоја, да реализује послове и пословање које би, макар и делимично, било независно од финансијске помоћи трећег или макро нивоа коме поред државе припадају и актери политичких коалиција (Табела 2). 
Јевтић Б., Систем спорта..., ФИЗИЧКА КУЛТУРА 2019; 73 (1): 1-22

Табела 2 Политичка идеологија и спорт (допуњено према Радојевић, Јевтић, 2011)

\begin{tabular}{|c|c|c|}
\hline Политички правац & Одлика деловања према спорту & Импликације на спорт \\
\hline Либерализам & $\begin{array}{c}\text { Минимално мешање државе, } \\
\text { индивидуализација и тржишна } \\
\text { оријентација }\end{array}$ & $\begin{array}{c}\text { Највећи број ресурса је усмерен ка } \\
\text { врхунском, елитном и комерцијалном спорту }\end{array}$ \\
\hline Социјализам & $\begin{array}{c}\text { Спорт је средство у решавању } \\
\text { различитих социјалних проблема и } \\
\text { остваривања оопштих интереса }\end{array}$ & $\begin{array}{l}\text { Директно мешање у све форме спорта, } \\
\text { законом омеђују активности и развој }\end{array}$ \\
\hline Конзерватизам & $\begin{array}{c}\text { Трагање за циљем, коришћење јавних } \\
\text { фондова је у другом плану, спорт је } \\
\text { бизнис }\end{array}$ & $\begin{array}{c}\text { На дистанци од спорта као приватне } \\
\text { иницијативе која је вођена од волонтерског } \\
\text { сектора }\end{array}$ \\
\hline Социјал-демократија & $\begin{array}{c}\text { Једнаке могућности за бављење } \\
\text { спортом }\end{array}$ & $\begin{array}{c}\text { Директна укљученост у спорт кроз изградњу } \\
\text { објеката и ширење учешћа свих грађана. } \\
\text { Јавно-приватно партнерство, спорт } \\
\text { заједници }\end{array}$ \\
\hline
\end{tabular}

Иако би се очекивало да је веза између мезо и макро нивоа двосмерна, ипак, на примеру Србије то није случај (Схема 2). Држава једносмерно делује према мезо нивоу, али и хотимичним мерама „прескаче“ овај ниво и директно делује према микро нивоу, пре свега према спортистима који се налазе у простору њеног интересовања. Стога, као да се ради се о виртуалној, нестварној вези, док су сами односи актера свих нивоа испуњени како суперпозицијом државе над спортом, спортистима, тренерима, тако и когнитивном и вредносном дисонанцом (сазнајни и вредносни несклад) по већини питања од значаја за тренутни и будући развој спорта и спортских грана. Под изговором „увођења реда“ дошло је до једносмерног деловања на актере свих нивоа система, што је довело и до застоја у управљању, самим тиме и у демократичности целине спорта и његових чинилаца. Мало је, или уопште нема спортских организација које су кадре да се самостално окрену свом развоју, да кроз културу свог организовања очувају аутономију својих управљачких и програмских одлука и активности. Очекивања од давања државе су изместила и обесмислила управљање спортом и спортским гранама, чиме је на неодређено одложен спортски, културни и пословни развој спортске организације. Овакво стање ближе описује слика 2 која садржи приказ анализе културе пословања за један број НСО-а током њиховог учешћа у олимпијским програмима за Игре у Лондону (2012). Уочљива је доминантна оријентација НСО-а према „југу вредносног компаса“. Нека ововремена анализа, вероватно би указала на још бројнију оријентацију НCO-а према југу вредносног компаса организовања и деловања. Другим речима, спортске гране у Србији се кроз своје НCO-е не креће у сусрет управљању менаџментом квалитета који води до тоталног (целовитог) управљања квалитетом чиме би и у систему спорта Србији доминирале лојалне, верујуће, компромисне, методичне, прецизне, брижне, чињеничне, солвентне.... спортске организације, кадре да усаврше свој „финални производ“ (спортиста, његов резултат, сама спортска организација, организација спортских такмичења, тренери...) али и оно што је још важније, да се усаврше у пословању и да српском друштву приреде и „испоруче“ спорт у складу са дефиницијом спорта коју је дао Савет Европе $^{5)}$, односно са очекивањима и потребама грађана Србије (Јевтић, 2014).

5) “Спорт је организована активност којом се остварују културне вредности, демократизује друштво, подиже квалитет живота и подстиче изградња националног идентитета кроз успехе појединца и тимова на такмичењима у захтевној међународној конкуренцији“. 


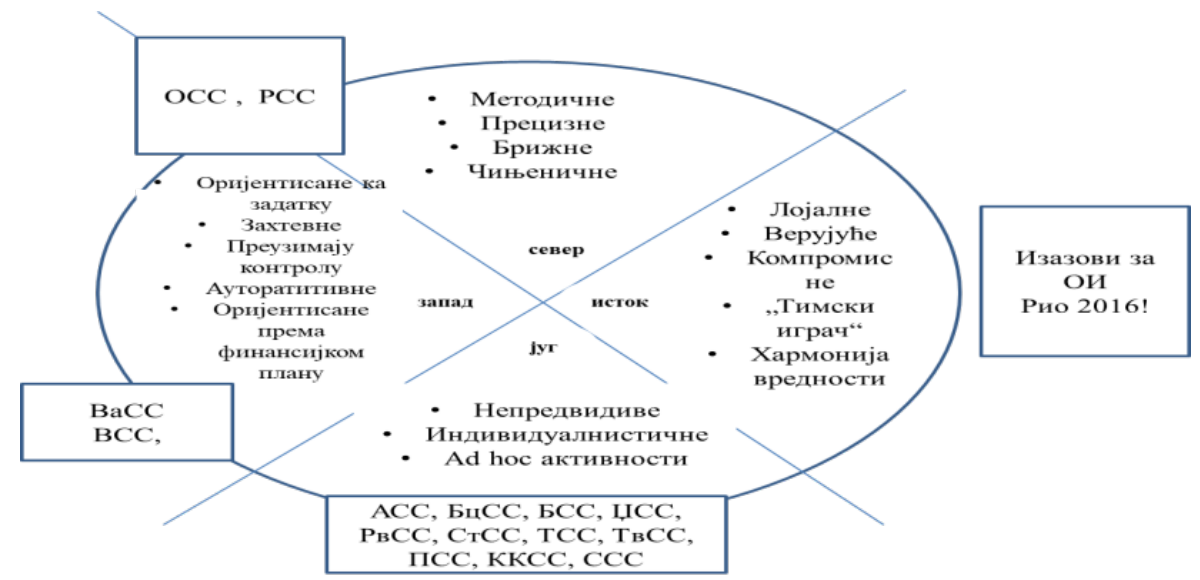

${ }^{*}$ Скрећенице за НСО спортова: Атлетика-АСС, Бициклизам - БсСС, Бокс - БхСС, Џуудо-ЈСС, Рване-РвСС, Стрельаштво - СтСС, Тенис - ТСС, Теквондо - ТеАС, Кајак-кану-КаСС, Стони-тенис-СтСС, Пливаюе - ПСС, Ватерполо-ВаСС, Веслане-ВеСС, Одбојка - ОСС, Рукомет - РСС

Слика 2 Компас модел оријентације појединих НСО Србије у односу на њихову асертивност према ОП (Јевтић, 2013).

\section{V}

Мало је писаних извора и докумената о животу и стварности система спорта у Србији пре пуне државне независности. Ипак, много тога, о периодукоји је претходио државној независности, може се закључити анализом чињеница и анализом смисла три документа НОК-а и то: пројеката „Атина 2004“ и „Пекинг 2008“, као и документа „Идејни оквир новог система спорта Србије“. Пројекат „Атина 2004“ садржи анализу квалификационих резултатата и управљање учешћем на овим Играма. Документ „Пекинг $2008^{“}$ обликује реализацију ОП у контексту како је дато на схеми 1. У оба случаја, ради се о документима организационог и технолошког развоја система спорта на нивоу међународног и врхунског спорта. Са друге стране, „Идејни оквир новог систем спорта Србије “ је документ сачињен са циљем: (1) уређења целовитог оквира система спорта у Србији, (2) преузимања одговорности старих и нових актера сва три нивоа организације система, као и (3) поделе задужења у новом националном систему спорта (Јевтић, 2011а).

Заједничко за наведена документа је да садрже анализе система спорта, именују проблеме, препознају актере, прописују активности које треба да подстакну еволуцију проолимпијског спорта и целине НСС. Проблеми који су детектовани и процеси који су именовани кроз ова три документа, и који су се са више-мање интензитета и успеха одвијали од 2006. године, могу се описати кроз две главне фазе као и већим бројем периода. Издвајањем фаза и периода, прецизније је могуће описати настојања и сам ток процеса изградње НСС. Овим се, такође откривају и (ис) кораци који су одредили степен прихваћености организационе, финансијске, управљачке савремености, као и чињења и нечињења која су довела до већег броја проблема у реализације мисије спорта 21. века. Специфично по фазама:

Током Прве фазе (2006-2009) одвијале се се хотимичне промене које се могу карактерисати као еволутивне у смислу њихове целисходности и прогресивне у смислу изградње целовитог, конзистентног, савременог и стабилног НСС. Региструју се периоди које описује усмереност ка решавању практичних проблема и изазова, као и избор активности које су довеле до промена у неким од циљаних простора функционисања система спорта, пре свега, у простору спортскомедицинске заштите спортиста, анти-допингу. Београд је био домаћин, а ОКС приређивач првог мултиспортског догађаја у Србији. Европски олимпијски фестивал младих (ЕYОF), одржан у лето 2007. године, оставио је резултатски успех али и бројно организационо, материјално и системско наслеђе, али и легат у кадровима различитих занимања и волонтерском организовању кроз спорт и за ширу друштвену потребу. Ово је фаза током које се у целости разрађују програми који воде до учешћа на 
олимпијским играма (Олимпијски програми ОП). Уочавају се знаци пословног и програмског „оздрављења“ спортских организација. Системом доминирају интенције НОК - ОКС, док се у делу организације Светских студентских игара „Универзијаде 2009“ региструје значајно учешће државе и политике. Национални олимпијски комитет интензивира договарања са државним структурама, од централне државе, покрајине Војводина, главног града и јединица локалне заједнице о финансирању ОП. Одговори за један број проблема, који хронично оптерећују спортисте, тренере, тренажни процес клубова, нађени су кроз заједничку активност са свим нивоима државне управе. Као добро и опортуно решење за многобројна питања спорта виђено је усвајање Устава Србије (2006) и препознавање спорта и физичке активности у најзначајнијим државном правном акту. Ту се није стало! Свесни ограничења према спорту која проистичу из дуалног организовања тадашњег Министарства просвете и спорта, спорт је сачинио и политици понудио документ којим је тражено оснивање министарства задуженог за спорт. Нека од питања врхунских - заслужних спортиста су решена кроз деловање Удружења олимпијаца Србије које је кроз Министарство просвете и спорта, покренуло, а Владе Републике Србије усвојила уредбу о националним признањима за спортисте и тренере.

Током прве фазе се интензивно ради на Закону о спорту и првој националној стратегији развоја спорта. Израда Стратегије је текла као координисан напор чланица система спорта и новоформираног МОС. И поред заједничког рада, овај документ је усвојен само од Владе Републике Србије. Изостало је усвајање на нивоу система спорта и приређивању програмских документа чинилаца спорта и његовог окружења у складу са циљевима и акционим планом овог документа. Стратегија приоритетно детерминише улогу државе у развоју спорта и иста се може окарактерисати са когнитивном и вредносном дисонанцом у односу на потребе система спорта европске државе 21. века. „Акциони план МОС се определио за државно управљање и државну иницијативу, аутистично се односи према систему спорта у ужем смислу, није оријентисан према развоју чинилаца самог система, већ кроз државни централизам жели да управља системом спорта чији није део. Епилог овог документа је да велики број зацртаних активности није реализован“(Јевтић, 2010).

Друга фаза у развоју система спорта у Србији траје од 2009. године. Током ове фазе уочавају се периоди којима доминирају промене које су у складу са насловом овог рада, и исте се могу сагледати и кроз проширење когнитивне и вредносне дисонанце, услед чега долази до одступања од постулата координисаног деловања спорта и државе. Особеност ове фазе је одустајање од консолидације управљања системом спорта кроз национални савет за спорт. Усвајањем Владине стратегије развоја спорта, до тада постојећи, неки облик партнерских односа спорта и државе, прераста у настојање државе да заузме лидерску позицију и доминацију у реализацији одабраних питања спорта. О томе докле се стигло првом, потом и другом Владином стратегијом развоја спорта, сликовито и више од сваког другог коментара говоре подаци у табели 3. Анализа ове табеле јасно истиче да се Влада препознала и да је стала у центар стратешких активности спорта у Србији! Полазиште за овај и овакав став се може наћи у искривљеној идејности система спорта у виђењу МОС (Схема 5). Данас, на истеку ове стратегије, учинак на њеној реализацији, као и реализацији Акционог плана су велика непознаница. Другим речима, мало је онога што ће остати као легат и на искуству заснована пракса и вредност у изради неке нове, и да се надамо савремене и спортоцентричне стратегије. 
Јевтић Б., Систем спорта..., ФИЗИЧКА КУЛТУРА 2019; 73 (1): 1-22

Табела 3 Стратешки приоритети и расподела активности за реализацију Акционог плана Стратегије развоја спорта РС (2013-2018)

\begin{tabular}{|c|c|c|c|c|c|c|c|c|c|c|c|}
\hline \multirow[t]{2}{*}{$\begin{array}{c}\text { Приоритети } \\
\text { унапређења области }\end{array}$} & \multirow[t]{2}{*}{$\begin{array}{c}\text { Планирани } \\
\text { број } \\
\text { активности }\end{array}$} & \multicolumn{2}{|c|}{$\begin{array}{c}\text { Централна } \\
\text { држава и јединице } \\
\text { локалне заједнице } \\
\text { - JЛ3 }\end{array}$} & \multicolumn{2}{|c|}{$\begin{array}{c}\text { Заводи за спорт } \\
\text { и АДАС }\end{array}$} & \multicolumn{2}{|c|}{$\begin{array}{c}\text { Систем спорта } \\
\text { (ОКС, ССС, } \\
\text { ПОКС и НСФ) }\end{array}$} & \multicolumn{2}{|c|}{$\begin{array}{c}\text { Академска } \\
\text { заједница и } \\
\text { струковне орг. }\end{array}$} & \multicolumn{2}{|c|}{$\begin{array}{c}\text { Остали } \\
\text { учесници }\end{array}$} \\
\hline & & $\begin{array}{c}\text { Број } \\
\text { активности }\end{array}$ & $\%$ & $\begin{array}{c}\text { Број } \\
\text { активности }\end{array}$ & $\%$ & $\begin{array}{c}\text { Број } \\
\text { активности }\end{array}$ & $\%$ & $\begin{array}{c}\text { Број } \\
\text { активности }\end{array}$ & $\%$ & $\begin{array}{c}\text { Број } \\
\text { активности }\end{array}$ & $\%$ \\
\hline Дечији спорт & 105 & 57 & 54 & & & 42 & 40 & 6 & 6 & & \\
\hline Рекреативни спорт & 138 & 85 & 61,5 & & & 26 & 19 & 4 & 3 & 23 & 17 \\
\hline Врхунски спорт & 68 & 25 & 33,1 & 5 & 7 & 31 & 46 & 7 & 10 & & \\
\hline $\begin{array}{l}\text { Спортска } \\
\text { инфраструктура }\end{array}$ & 39 & 21 & 54 & 7 & 18 & 11 & 28 & & & & \\
\hline $\begin{array}{l}\text { Спорта на свим } \\
\text { нивоима власти }\end{array}$ & 138 & 28 & 21 & 54 & 41 & 56 & 42 & & & & \\
\hline $\begin{array}{l}\text { Истраживачки рад } \\
\text { у спорту }\end{array}$ & 85 & 20 & 24 & 26 & 31 & 20 & 24 & 19 & 22 & & \\
\hline $\begin{array}{l}\text { Број и } \\
\text { дистрибуција } \\
\text { свих активности } \\
\text { (\%) }\end{array}$ & 573 & 236 & 41 & 92 & 16 & 186 & 32 & 36 & 6 & 23 & 4 \\
\hline
\end{tabular}

* Планирано учешће спортских организација (осенчено) у реализацији стратегије развоја спорта 2013-2018 је 32\%. Учешће државе и институција основаних декретима државе, које се финансирају из државног бущета и не припадају систему спорта је 68\%.

Спорт је, како од прве, тако и од друге стратегије и пратећих акционих планова, очекивао

афирмацију специфичности спорта и јачање његове аутономије. Очекивало се окончање професионализације саме спортске организације према зацртаном у Стратегији из 2009. године, и којом је предвиђено да ће се у првом кораку (периоду) радити на стандардизацији организована (стандардизација структуре и стандардизација националних гранских савеза, њихове организације, администрације, програма и др.). Као други корак (2010-2012) била је именована специјализација спортске организације (кроз принципе атрактивности спорта физичког вежбања, афирмацији талената, развоју ресурса за врхунски спорт). Трећи корак (20122013), требало је да изнедри „Нови систем спорта у складу са потребама и очекивањима српског друштва у двадесет и првом веку, али и у складу са Европском спортском повељом, принципима политике спорта за све, Кодексом спортске етике, Конвенцијом о спречавању насиља у спорту, Конвенцијом о спречавању допинга у спорту“ (Стратегија, 2009). У Акционом плану за спровођење Стратегије 2009-2013 предвиђено је и јачање аутономије спортских савеза у регулисању унутрашњих односа сваке спортске гране, као и у одређивању праваца развоја. Аутономија није мали изазов, јер иста значи да спорт регулише сам себе, чиме се постиже његов квалитет, кредибилитет и легитимност (Chappelet, Bayle, 2005; Chappelet, 2010). С тим у вези, стратегије спорта Владе Србије, како она из 2009, тако и она из 2013. године, као и Закон о спорту (2009), предвиђају формирање Националног савета за спорт. Савет за спорт је требало да обавља лидерску функцију у консолидованом систему спорта и исти би био „кишобран“ аутономије и заштите специфичности спорта и његових актера у Србији. Иако се знало да је аутономија спорта, како у свим њеним суштинским облицима (политичка, правна, финансијска, пирамидална, надгледана, функционална, преговарачка, као и аутономијадоброг руковођењауспорту, (Mrkonjic, 2013)), тако и у њеном пуном капацитету, изазов и за старије демократије Европе, ипак, није се очекивало да ће реализација овог стратешког циља бити занемарена - потиснута. Још се мање 
очекивало да се промене у систему спорта у Србији неће одвијати према упутствима Савета Европе којима се штити аутономија спорта. Наиме, и сам Савет Европе, свестан угрожености аутономије спорта од стране политичких и државних структура, идентификовао је и описао хоризонталну и вертикалну мрежу и предочио односе актера ове две мреже, са циљем заштите аутономије спорта. Тако, хоризонталној мрежи на нивоу Европе припада деловање организације и тела која се спортом баве у име Савета Европе и Европске комисије (енг. EPAS), конференција министара задужених за спорт (енг. MINEPES), струковна удружења (тренера, наставника физичког васпитања, научника у спортским наукама, менаџера, факултета спорта и физичког васпитања, националних тренажних центара...). Вертикална мрежа се реализује од нивоа клуб, преко НСО, НОК до међународних спортских организација и самог Међународног олимпијског комитета. Вертикална мрежа је искључиво право организовања правих чинилаца система спорта (спорт у ужем смислу, слика 1). Документ СЕ прописује да је забрањена, или није оправдана и очекивана суперпозиција актера хоризонталне над чиниоцима вертикалне мреже, јер то доводи до државног интервенционизма (Chaker, 1999, 2004). У примеру Србије, велики број одлука из надлежности вертикалне мреже доноси држава, као субститутор непознате политике и интересних група. Наведено упућује на закључак да систем спорта у Србији није на путу изградње консолидованог система и модела управљања, којим би спорт био самосталан и аутономан у доношењу одлука свог развоја, био партнер свим актерима друштва и деловао у сагласју са њиховим агендама и циљевима развоја Србије. На снази је државни интервенционизам, због чега Србија није у организационом и легислативном сагласју са већином земаља Европске Уније, па тако и у делу струке спорта драматично различито видимо систем и национални спорт од Словеније и Хрватске са којима смо чинили систем спорта бивше СФРЈ.

Законом о спорту који је усвојен 2009. године, а нарочито Законом о спорту из 2016. године постало је јасно да неће бити уређења система спорта у Србији у складу са потребама спорта 21.века. Од почетног ентузијазма из 2006. године стигли смо до државног интервенционизма кога најбоље описује Схема 5. Иако је ова схема сачињена од чиновника MOC-а, и иста је повучена из јавне расправе Стратегије из 2013. године, ипак се њена смисленост задржала у текстуалном изразу овог владиног документа. Другим речима, систему спорта Србије је ускраћено право (или се систем сам одрекао тог права?) да изгради своју самосталну, аутономну и спорту одговорну управљачку страну. Није се консолидовао у корист спортског и олимпијског покрета. Све упућује на то да управљање спортом од стране самог спорта није прихватљиво државним и политичким елитама Србије, које због тога доносе директиве, законе, прописе, уредбе, врше надзоре и кажњавају спортске организације. На делу је, когнитивна-организациона-вредноснатехнолошка-политичка ... дисонанца између бића спорта, потребе грађана и целине друштва са једне и државе и политичких партија са друге стране.

\section{ОД ИНОВАТИВНИХ \\ ИСКОРАКА ДО ДРЖАВНОГ ИНТЕРВЕНЦИОНИЗМА}

Иако две фазе у развоју система спорта у Србији делују супротстављено, ипак, оне су врло блиске и међусобно су прожете. О томе, примером говори учињено - неучињено на афирмацији учешћа жена у спорту (Табела 4). 
Табела 4 Закључци о системском деловању по питањима учешћа жена у спорту (Јевтић, 2011в)

\section{0}

- Анализирати међународну спортску сцену и пут постизања врхунских резултата у конкуренцији жена

- Успоставити активност струковних удружења (тренера, менаџера, лекара спортске медицине, спортских научника...).

- Усвојити национални стандард и оквир радног места у спорту.

- Здравствену заштиту учинити доступном и обавезном.

- Разрадити принципе управљања каријером и посткаријером спортисткиња.

- Сачинити инструменте за контролу тренинга и програма припрема.

- Успоставити проток информација.

- Радити на Моделу улога у промоцији спорта жене
2011

- Не региструје се активност на формирању струковних удружења (тренера, менаџера, лекара спортске медицине, спортских научника...).

- Здравствена заштита је доступна свим спортисткињама.

- Сачинити инструменте за контролу тренинга и програма припрема.

- Успоставити базу података и проток информација.

- Радити на Моделу улога у промоцији спорта жене.

- Системски интервенисати на нове статуте НСО ( у току усаглашавања са Новим законом о спорту), као и на програмске оквире које ће НCO номиновати кроз ОКС и ССС.
Основе за државни интервенционизам постављене су на самом почетку државне независности и то због непознавања или недовољне истрајности самог спорта на паневропским повељама и директивама које се тичу самоорганизовања и очувања аутономије и специфичности спорта. У тој 2006. години, током припрема за ново - старо политичко уређење али ново друштвено окружење, изостало је изучавање и места и улоге спорта у правцу друштвеног прогреса. Као и код већине посткомунистичких земаља, које су у скорашње време мењале своје уставе, тако су и у Србији, спорт и физичка активност грађана унети у Устав (2006). Онолико колико уставна категорија обезбеђује сигурност за одвијање спорта у једној земљи, толико то аутоматски укључује специфичну легислативу коју доноси држава и која се односи на спорт (Petry, Steinbach, Tokarski, 2004). Да устав није conditio sin qua non одвијању спорта могло се научити из анализе југословенске прошлости, али и из докумената Савета Европе (Chaker, 2004), или из паневропске праксе у присуству јавних власти и закона у одвијању спортских активности (Carrard, 2006). Самосталан и афирмисан национални систем спорта, а не његова уставна категорија одређује успехе спорта у Финској, Француској, Немачкој, Холандији, Великој Британији, али и Словенији (Chaker, 1999). Неки би рекли да се ради о англо-саксонском приступу овој материји. Другим речима, уз настојање да именујемо спорт као уставну категорију, добили смо низ законских и подзаконских докумената којима се јачала државна надлежност у спорту. Држава је Законом о спорту (2016) прешла из субсидијарног у водећи ауторитет српског спорта. Стога, учињено око спорта као уставне категорије и данас се може квалификовати као довољно непромишљена активност, преурењана или интенција која није била усаглашена са демократским карактером друштва и политичког система, чиме је постала слаба карика за афирмацију аутономног система спорта. Ова одлука се може ближе описати и произведеним ефектима:

1. Одсуство консолидованог управљања спортом, односно извршена је нека врста консолидације система спорта и то у корист политике. На овом месту треба нагласити да се консолидација система чини ради остваривања суштинских циљева спорта, и њоме се, у деловању према политици, чувају унутрашње структуре аутономног функционисања спорта. Њоме се стреми једном, „јаком гласу“ који ће представљати спорт, јер сходно Повељи о спорту Савета Европе, спорт и држава стоје у комплементарном односу, а не у односу суперпозиције државе над спортом. Анализе докумената спорта и Владе, али и изјава званичника спорта Србије указују да се систем 
спорта настојао консолидовати (до 2009), да би потом, притиснут законским решењима, то место уступио државној управи и њеним формалним и неформалним представницима. За историчаре спорта важно би било одредити околности под којима се то десило, за аналитичаре система спорта је важније како је то изведено. Где се систем спорта „саплео“ и како није уочио шта му се спрема? „Знакова поред пута“ је било много, али их спорт није умео или није желео да прати и чита или се можда плашио последица?! Остаће записано да су се поводом јавне расправе првог закона о спорту државно независне Србије, током 2009. године, јавно огласиле само две спортске организације, и то Олимпијски комитет Србије (ОКС) и Фудбалски савез Београда. Тадашња министарка омладине и спорта о примедбама ОКС на предлог закона каже: Ми (коментар аутора: читај Држава) овим законом, уводимо ОКС у систем српског спорта. Тренутно важећи закон (мисли се на закон о спорту из 1996. године) уопште не помиње ОКС , тако да формално гледано они нису део спортског система. Министарка наставља: „У новом нацрту закона ОКС се веома уважава и помиње 16 пута.... Оно што можда збуњује ОКС јесте место те институције у српском спорту. Они имају амбиције да, како они кажу, буду „капа српског спорта“. То није логично, ни могућно! Оно што је у овом закону експлицитно и важно јесте да нико није „капа спорта“, осим да на врху спортске пирамиде стоји Министарство омладине и спорта. То јесте логично, јер спорт се највећим делом финансира из државног буџета. А Министарство се ослања на невладин сектор, на гранске спортске савезе, ОКС и Спортски савез Србије“ (Вечерње новости, 07.06.2009).

Анализом и примером овог интервјуа може се закључити да је одлука по питању националног спорта које се тиче консолидације и управљања његовим системом, донета од стране Парламента Србије, а на предлог једног државног службеника или партије којој он припада. Све личи на примере из комунизма током кога се спорт користио за политичке циљеве у којима су се националне спортске организације константно бориле за идентитет и аутономију спорта (Jeu, 1994). Национални олимпијски комитет је независна спортска организација која је conditio sin qu non модерне државе, макар је тако у већини земаља ЕУ. Постоји неколико случајева покушаја контроле НОК од стране националних влада у Африци, Латинској Америци и Азији. Са друге стране, државни орган на нивоу министарства задуженог за спорт има мали број европских земаља. Олимпијски комитет Србије постоји од 1910. године, то је спортска организација која прати развој свог друштва и своје државе. За више од века постојања ОКС је постао „културна институција“ која предводи век српске спортске и олимпијске традиције и, увек је био носилац прогреса и процеса интеграције српског друштва у модерна друштва Европе и света кроз спорт и олимпизам.

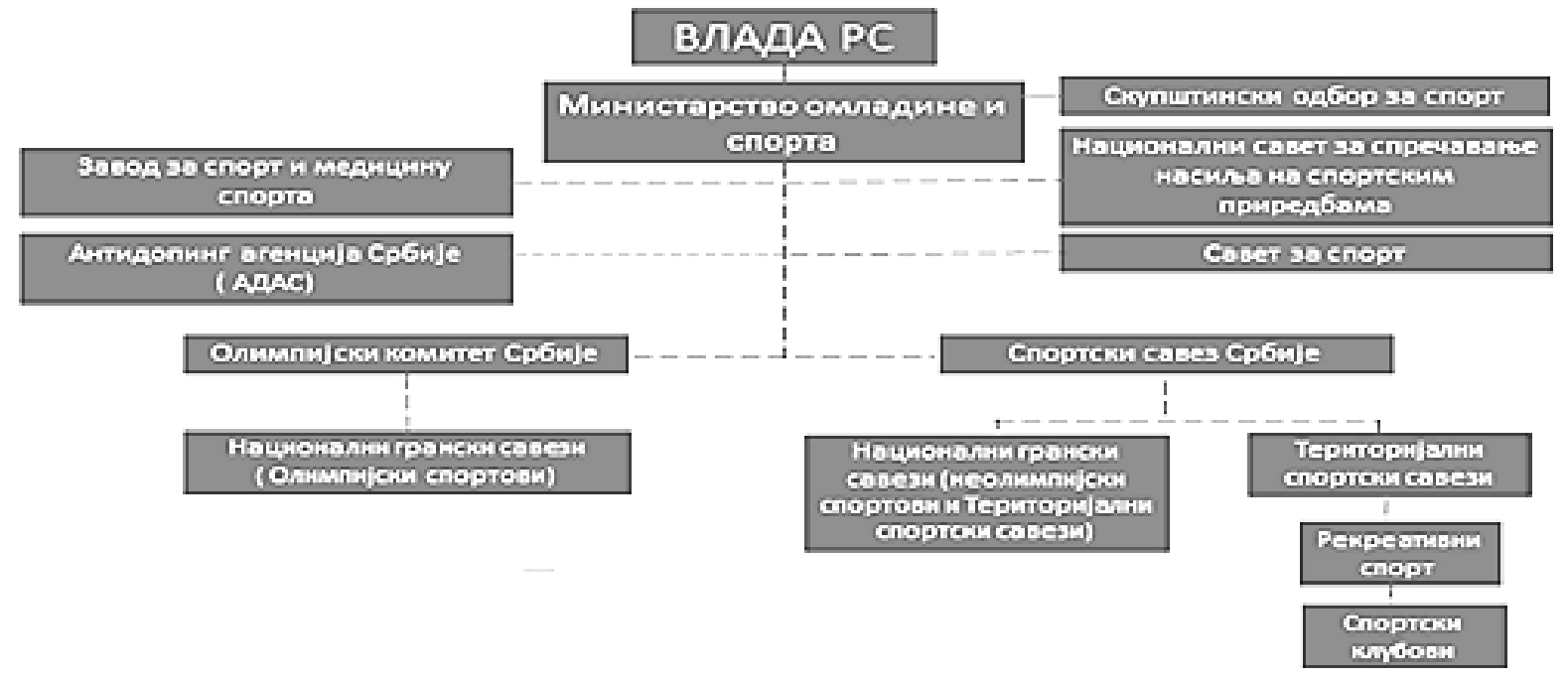

Схема 5 Систем спорта у виђењу Министарства омладине и спорта (2013) 
Да би расправа о односу НОК и државе била јаснија, треба знати да водећу националну спортску организацију описује пет елемената, и то њен друштвени идентитет, укљученост у спорт, усмереност, организација и функционисање, као и њено препознавање (Slack, Parent, 2006). Органи владе задужени за спорт, нигде у свету немају атрибута којима би се могли препоручити за учешће у систему спорта, још мање у управљању његовом организацијом и деловањем, Тешко је говорити о бићу министарства ван оног политичког, бирократског, технократског и партократског. Министарству спорта, ако већ постоји као део организације државне управе, у демократским друштвима припада деловање кроз хоризонталну мрежу, тачније место у окружењу система спорта и на макро нивоу организовања спорта. Министарство спорта је одговорно за креирање окружења за развој спорта у држави, кроз имплементацију државне стратегије и координацију владиног и невладиног сектора. Тако МОС у Србији треба, између осталог да: (1) повеже систем државне управе делујући према државним структурама (Министарство финансија - буџет, игре на срећу, порези, донације....Министарство науке научни пројекти, истраживање утицаја спорта на становништво, одрживи развој, информационе технологије и информатичко друштво....Министарство за инфраструктуру - изградња спортских обејката и њихово место у развоју градова и регија (олимпијски и национални тренинг центри....; Министарство локалне управе - спорт на локалном нивоу, концепција, простори, развој и разуђеност објекта, приоритети локалних заједница и реализација државне стратегије у спорту на локалном нивоу...Министарство просвету - интеграција спорта и физичког васпитања, васпитна функција спорта, квалитет физичког васпитања и школског спорта, школски објекти као ресурси за дечији и омладински спорт....Министарство здравља - спорт и здравље, превентива, систем спортско-медицинске заштите и здравственог осигурања спортиста...) Постоје блиске везе између активности МОС и министарстава правде, одбране, унутрашњих послова, рада и социјалне политике, иностраних послова..., како у делокругу изградње окружења система спорта, тако и у делу учешћа у самом систему спорта (војни и спорт у полицији). (2) Са чиниоцима самог система спорта (НСО, ОКС; ССС...) учествује у развоју и уређењу целовитог система спорта (Јевтић, 2010).

Питања финансирања спорта од стране државе се наметнуло као „крунски“ аргумент у освајању лидерске позиције на пирамиди спорта Србије. Колико је и какво финансирање спорта у Србији о томе ближе говори анализа Економског инсититута из Београда која је показала да је у 2011. години, „спорт у Србији губио 79 милиона евра годишње због постојања „црног тржишта игара на срећу“ Износ у финансирања спорта од стране државе (централне и локалне) износи око 80 милиона евра. Због законског гушења волонтерске организације спорта и непостојања вредновања волонтерског рада у спорту, у Србији ce, по наводима исте анализе, не идентификује скоро 200 милионара евра индиректног учешћа у финансирању спорта и развоју српског друштва“ (извор MOC, www.mos.gov.org.rs/analize).. Изостанак у организацији комерцијалног и приватног спорта, јавно-приватног партнерста и дефинисању једног дела спорта као привредне делатности..., изостало је препознавања индустрије спорта (Јевтић, 2014) која се високо котира у простору привредне активности на свету (више од $4 \%$ укупног годишњег богатства света се остварује кроз спорт). Наравно, за пуну истину о токовима финансирања спорта адреса није МОС, већ то су подаци Еуростата, исказано за све земље ЕУ. Па тако, како у Европи, тако и у САД и широм света, породица је та која са више од $50 \%$ учествује у директном финансирању спорта. Процењује се да свака породица годишње издваја до 4\% свог буџета за учешће својих чланова, пре свега деце у спорту, од чега скоро 60\% троше за набавку опреме, реквизита и обуће. Другим речима, када се саберу сви индиректни и директни извори финансирања спорта, централна држава и локална заједница, по оцени Еуростата, директно финансирају спорт са мање од 30\%. Конкретно, према студији Факултета спорта из Келна (2011), за целину Европске уније (27 земаља) у 2008. години, укупан буџет је износио 182,2 милијарди евра и садржао је директна давања спорту у износу од 71.7 милијарди евра, 28.2 милијарде је процењена вредност волонтерског рада у спорту док је 82.1 милијарде евра потрошено од 
стране породица за куповину опреме, реквизита, спортске обуће и слично ${ }^{6}$.

У примеру Немачке, централна држава улаже око 360 милиона евра у спорт годишње (4-4,5 евра по становнику) док се из пореза на додатну вредност (ПДВ) од продаје робе и услуга у спорту повлачи скоро милијарду евра (Breuer, 2009). Анализа о поврату новца кроз порез на додатну вредност из спорта Србије нема. У пракси, тај поврат се у Србији креће и до 70\% од уложеног од централне државе и локалних самоуправа. Колики је поврат од улагања родитеља, спонзора, међународних спортских организација, привреде, конзорцијума, спортског туризма, организације спортских догађаја...., односно колико је хотимично одрицање прихода од лутрије, кладионица и игара на срећу, другачије пореске и фискалне политике у корист спорта, то се може, апроксимативно проценити примером Немачке или било које од 28 земаља ЕУ, и закључити да спорт друштву ствара додатну вредност која се у примеру Србије транспарентно не враћа у простор спорта као провереног и абирмисаног средства за васпитане и образоване младих, здравље наиије, промоиију државе....

2. Интервенционистички тип спортске легислативе је израз постојећег државног уређења, политичке идеологије и степена демократичности друштва у коме се живи. Између децентрализованог модела, којим се спорт финансира од стране локалних и регионалних власти, ми у Србији живимо у друштву са прерогативима јаке централне државе. То што рецимо Италија има закон о спорту (из 1947) са НОК на врху спортске пирамиде, не представља проблем да она у управљању спортом буде децентрализована и да се спорт финансира из

\footnotetext{
6) Учешће у директним трошковима спорта од 71.7 милијарди евра буџета држава ЕУ припада:

- 40,4 милијарда или 56,3\% кућном буџету

- 23,4 милијарди или $32,6 \%$ јединицама локалне заједнице

- 5.3 милијарди или 7,4\% централној држави, од који су 2.1 милијарда или $40 \%$ су од лутрије, клађења и игара на срећу

- 1,6 милијарди или око $2.2 \%$ спонзорству и донацијама привреде-компанија

- 0,5 милијарди или 0,7\% медијских права

- 1.1 милијарди или 2,2\% од лутрије, клађења и игара на срећу од којих се 90\% прослеђује кроз државни буџет, а неких 10\% се распоређују директно спортским организацијама

- 400 милиона евра из других, укључујући и фондове ЕУ.
}

локалних и регионалних извора. У припреми Закона о спорту у Србији, од два могућа субмодела државног интервенционизма (легислативни и финансијски), законописац је изабрао оба, јер је очито проценио да само тако, целовито, може да одређује и омеђује структуру, организацију, функцију, независност.... система спорта. Очито је да проевропска пракса да се континуирано обезбеђује финансијска и логистичка помоћ спорту није била довољно изазовна амбиција за државу и појединце из политике у Србији. Они су усмерени и на управљачку страну спорта. Другим речима, у простору законског регулисања спорта нису нам узор биле Немачка, Холандија или Велика Британија које немају специфичне законе о спорту, или Италија, Аустрија или Швајцарска које су уставима извршили демаркацију моћи између спорта и централне и државе на локалном нивоу (Chaker, 2004), односно Чеша Република која се определила ка неинтервенционистички закону о спорту. Учињено у Србији само привидно сличи решењима бивших комунистичких земаља и нових чланица ЕУ (Мађарска, Хрватска, Литванија, Румунија...). Оно по чему се разликујемо од источних и западних земаља континента, али и окружења јесте непостојање лидера у управљању НСС. Пракса организовања и функционисања система спорта познаје консолидован модел у корист једног лидера на врху спортске пирамиде. Најчешће је то савет за спорт или НОК, као што се ради у Француској, Хрватској, Италији, Словенији. Други је конфедерални модел консолидације управљања системом спорта. У овом моделу, спортом управљају лидерска територијална спортска организација и национални олимпијски комитет. Ово је модел који је афирмисан у решењима Немачке, Шведске, Данске.

3. Фрагментација система спорта. Епилог интервенционистичке природе легислативе је и процес растакања целине система спорта. Систем спорта Србије данас описује одсуство организационог и управљачког врха спортске пирамиде у више од 160 националних спортских организација. Процес регистрације нових НСО и даље тече и одвија се кроз државну управу према којој су померене изворне надлежности спорта, као што је препознавање, регистрација и чланство у њеном „виртуалном систему спорта“. Теорија организације се спутала у Србији, јер су препознавање и управљање важан део спорта, док 
су руководећа тела сачињана на тај начин дужна да испуне мисију организације унутар окружења у коме организација функционише.

\section{ЗАКљУЧАК}

Анализа система спорта је сложен сазнајни процес који се углавном спроводи коришћењем квалитативних метода истраживања. Методе истраживања из процесне социологије и менаџмента у спорту се користе у циљу описа феномена, откривања веза и формирању закључака. Систем спорта се анализира и кроз методологију наука које се баве друштвом и његовом динамиком.

До закључака по предмету овог рада, а то је систем спорта у Србији од 2006. године, од дана државне независности до данас, дошло се индуктивно-дедуктивним сазнајним путем, анализом докумената као и рефлексијом на велики број чињеница и изазова који су пратили и утицали на ток промена НСС.

О систему спорта у Србији може да се закључи да он није систематичан, да је централизован, није аутономан и да је од државе високо и вишестрано зависан. Није демократичан, под сталним је дејством чинилаца који не припадају систему спорта. Финансијски није солвентан, изгубио је волонтерско биће, не бележи значајан напредак у масовности, смањио се број спортиста и спортских грана које успевају да се квалификују и наступе на ОИ. Бележи се значајније учешће спортисткиња у делегацијама за олимпијске игре и друге мултиспортске догађаје.

Иако није био предмет ове анализе, ипак, анализирани период садржи и чињенице о слабости система спорта и на делу:

\section{ЛИТЕРАТУРА}

1. Bergsgard, A.N.; Houlihan, B.; Mangset, P.; Nodland, I.S.; Rommetvedt, H. (2007). Sport Policy, A Comparative Analysis of Stability and Change. Elsevier, Singapore

2. Blouce, D.; Smith, A. (2010). Sport policy and Developement. London: Routledge.
- међународне спортске сарадње, при чему, пријем тзв. „Косова“ у МОК и међународне спортске организације упућује да нам нису блиска правила међународног спорта и односа који владају у њему, те се тако овај пријем може сматрати епилогом изостанка унутрашњег консензуса, мешања политике у спорту, недостатака стратегије, инертности појединаца али и целих организација, нечињења и-или ометања у бављењу овим проблемом у времену које се могло сматрати опортуним за његово решавање (закључно са ОИ у Лондону);

- професионаланог спорта коме припадају спортски клубови који нису финансијски солвентни док издвајања за учешће у лигашким такмичењима нису у функцији припреме и учешћа спортиста ових клубова у врхунском аматерском спорту, укључујући и наступ на олимпијским играма;

- комерцијални спорт, приватни спорт, универзитетски спорт, јавно-приватно партнерство у спорту... нису у агенди ни за трећу декаду овог века.

Систем спорта у Србији нема свог лидера. Држава и политика су се „улиле“ у спорт у коме, са суперпозиције финансијске, законодавне и политичке моћи, делују на чиниоце и актере спорта, стога, спорт и даље трага за својим вредносним, организационим, програмским и управљачким идентитетом. Промене које су планиране и делимично реализоване и од којих се очекивало да доведу до сусретања са паневропским моделом спорта су „скренуле“ са пута промишљеног и иновативног развоја на пут исцрпљујућег и непросперитетног државног интервенционизма непознатих исхода.
3. Breuer, C. (2009). Sport Development Report 2007/2008, Analysis of the sports clubs, situation in Germany. Bundesinstitut für Sportwissenschaft, Medienhaus Plump, Rheinbreitbach Bonn.

4. Camy, J.; Robinson, 1. (2007). Managing Olympic Sport Organizations. Lausanne: Olympic Solidarity and Human Kinetics. Champaign, IL 
5. Carrard, F. (2006). Autonomy of sport, comments. In R. Mitchell and P. Baummann Rapporteurs: First Seminar on the Autonomy of the Olympic and Sports Movement. International Olympic Committee, Lausanne.

6. Chaker, N.A. (1999). Study on national sport legislation in Europe. Council of Europe Publishing, Strasbourg.

7. Chaker, N.A. (2004). Good Governance in Sport, A European Survey. Council of Europe Publishing, Strasbourg.

8. Chappelet, J.L; Bayle, E. (2005). Strategic and Performance Management of Olympic Sport Organisations. Human Kinetics, Champaigin, Il.

9. Chappelet, J.L. (2010). Autonomy of sport in Europe. Council of Europe Publishing, Strasbourg.

10. De Bosscher, V.; Bingham, J.; Shibil, S.; van Bottenburg, M.; De Knop, P. (2008). The Global Sporting Arms Race. An International Comparative Study on Sports, Policy Factores, Leading to International Sporting Success. Meyer\&Meyer Sport (UK)Ltd.Oxford.

11. De Senci, J (1990). Sport management circular evaluation and needs assessment: A multifaceted approach. J. of Sport Management 4: 31-58.

12. Deutsche Sporthochschule Köln (2011). Study on the funding of grassroots sports in the EU. Köln

13. Digel, H. (2001). Talent identification and promotion. European Olympic Committee Technical Seminar Book, "Organisation of Talent Identification and Promotion", pp 10-29. Berlin.

14. Edwards, A.; Skinner, J. (2009). Qualitative research in Sport Management. Elsevier, Ltd. Singapore.

15. Евтич, Б. (2013). Олимпийская программа в контексте развития системы национального спорта. Наука в олимпийском спорте, 1: 27-37.

16. Jevtić, B. (2010). Sistem sporta, sportski stručnjaci i bolonjski proces. U G. Kasum i sar. Angažovanost nastno-naučnog kadra sa akreditovanih državnih fakulteta sporta u okviru aktivnosti nacionalnih sportskih saveza $i$ eltinih klubova u stručnog kadra iz nacionalnog sporta $u$ sistemu obrazovanja $i$ usavršavanja na akreditovanim sportkim državnim obrazovnim instirucijama. str.7-31. Beograd Fakultet sporta i fizičkog vaspitanja i Ministarstvo omladine i sporta.
17. Jevtić, B. (2011a) Refleksija menadžmenta olimpijskih programa na sistem sporta Srbije. SportLogia 7 (2) 129-140, doi 105550 / sgia110702se129J

18. Јевтић, Б. (2011a). Систем спорта и дечији спорт. У Б. Јевтић, Ј. Радојевић, И. Јухас, Р. Ропрет (ед) Дечији спорт од праксе до академске области (стр 69-91). Факултет спорта и физичког васпитања, Београд.

19. Jevtić, B. (20116) The Path of True Values. ACC Journal, Social Science and Economy. XVII : II 8287

20. Јевтић, Б. (2011в). Жена у програмима ОКС искуства претходног и стратегија олимпијског циклуса 2008-2012. Физичка култура, 65(c1): 29-41.

21. Jevtić, B. (2012) Upravljanje programima za učešće na mega sportskom događaju. Management, 63: 63-75.

22. Jevtić, B. (2014). Sport and enterpreneurship. In Proceedings "Techology, Culture and Development", pp 122-134, Belgrade. Asosciation Technlogy and Society.

23. Јевтић, Б. [2017]. Научни часопис «Физичка култура» у мисији развоја научне и друштвене заједнице. Физичка култура, 71(2), 182-194.

24. Jeu, B. (1994). Sports and Social and Cultural Phenomenon. In "For Humanism of Sport", Ed of. Comite National Olympique et Sportif Francais, Paris

25. Kay, T. (2012) Accounting for legacy: monitoring and evaluation in sport in development relationships, Sport in Society, 15:6, 888-904, doi: 10.1080/17430437.2012.708289

26. Loland, S. (2009) The Ethics of PerformanceEnhancing Technology in Sport, Journal of the Philosophy of Sport, 36:2, 152-161, doi: 10.1080/00948705.2009.9714754

27. Mrkonjic, M. (2013). Sports organisations, autonomy and good governance. Working paper for Action for Good Governance in International Sports Organisations, (AGGIS) project. https:// www.researchgate.net/publication/323696569

28. Petry, K., Steinbach, D., \& Tokarski, W. (2004). Sport systems in the countries of the European Union: Similarities and differences. European Journal for Sport and Society, 1(1), 15-21. 
29. Slack, T., Parant, M.M. (2006). Understuding Sport Organization: The Application of Organization Theory. Human Kinetics, Champaigin, Il.

30. Вукашиновић, В. (2018). Владан Ђорђевић, живот и дело вежбача, научника, политичара, књижевника, утемељивача српске гимнастике и соколства. Физичка култура, 72(1), 5-19

31. Радојевић,J., Јевтић, Б. (2011). Друштво и спорт деце и омладине. У Б. Јевтић, Ј. Радојевић, И. Јухас, Р. Ропрет (ед) Дечији спорт од праксе до академске области (стр 31-44). Факултет спорта и физичког васпитања, Београд.

32. Šuput, D. (2015). Nastajanje sportskog prava Evropske unije. Strani Pravni Život, 2:99-115.

\section{Документа}

1. Јевтић, Б. (2006). Идејни оквир новог система спорта Републике Србије. Заједничка седница чинилаца система спорта Србије. Олимпијски комитет Србије, Београд.

2. Јевтић, Б. (2006-б). Пројекат ОКС „Пекинг 2008“. Олимпијски комитет Србије, Београд.
3. Јевтић, Б. (2009). Пројекат „Олимпијска Србија“. Олимпијски комитет Србије, Београд.

4. Министарство омладине и спорта (2008). Национална Стратегија развоја спорта у Републици Србији (2009-2013 и 2013-2018): www.mos.gov.rs

5. Jevtić, B., Manojlović, P. (2014). Finalni dokumet sa akcionim planom u oblasti vrhunskog i profesionalnaog sporta i medjunarodne sportske saradnje. Olimpijski komitet Srbije.

6. European Council (2000) Declaration on the Specific Characteristics of Sport and Its SocialFunction in Europe

7. European Commission (2007) White Paper on Sport

8. European Commission (2011) Developing the European dimension in sport

9. Council of Europe (1992). European Sports Charter

10. United Nations (2000). Controbution of Sport to the Millennium development goals (www.un.org/ sport/sites/www.un.org.sport/files/documents/ pdfs/) 